149/4, 371-394., Budapest, 2019

\title{
The use and beauty of ultra-high-resolution seismic reflection imaging in Late Quaternary marine volcaniclastic settings, Bay of Naples, Italy
}

\author{
Sacchi, Marco ${ }^{1,2}$, Caccavale, Mauro ${ }^{2,3}$, Corradino, Marta ${ }^{4}$, Esposito, Giuseppe ${ }^{5}$, Ferranti, Luigi ${ }^{6}$, Hámori, Zoltán $^{7}$, \\ $\dagger$ Horváth, Ferenc $^{7,8}$, Insinga, Donatella ${ }^{2}$, Marino, Camilla ${ }^{6}$, Matano, Fabio ${ }^{2}$, Molisso, Flavia $^{2}$, NATAle, Jacopo $^{6}$, \\ PASSARO, Salvatore ${ }^{2}$, PEPE, Fabrizio ${ }^{4}$, TóTH, Tamás ${ }^{7}$ \\ ${ }^{1}$ corresponding author, e-mail: marco.sacchi@cnr.it, ${ }^{2}$ Istitute of Marine Sciences (ISMAR), Italian Research Council (CNR), Napoli, Italy \\ ${ }^{3}$ Istituto Nazionale di Geofisica e Vulcanologia (INGV), Napoli, Italy, ${ }^{4}$ Dipartimento di Scienze della Terra e del Mare (DiSTeM), Palermo University, \\ Palermo, Italy, ${ }^{5}$ Research Institute for Geo-hydrological Protection (IRPI), Italian Research Council (CNR), Cosenza, Italy, ${ }^{6}$ Department of Earth \\ Sciences, Environment and Resources (DiSTAR), Napoli University "Federico II" Napoli, Italy, ${ }^{7}$ GEOMEGA - Geological Exploration and \\ Environmental Services Ltd., Budapest, Hungary, ${ }^{8}$ Department of Geophysics and Space Science, Eötvös Loránd University, Budapest, Hungary
}

\section{Ultra nagy felbontású reflexiós szeizmikus képalkotás haszna és szépségei: késó-negyedidőszaki tengeri vulkanoklasztos felépítmények a Nápolyi-öbölben}

Összefoglalás

A Nápolyi-öbölben felvett ultra nagy felbontású egycsatornás (IKB-Seistec ${ }^{\mathrm{TM}}$ ) reflexiós szeizmikus szelvények korábbi geológiai és geofizikai vizsgálatok eredményeivel együtt kivételes, eddig soha nem látott felbontású szeizmikus leképezését nyújtják a Flegrei-mező́k és a Somma-Vezúv felszín alá süllyedt késő-pleisztocén-holocén rétegtani felépítésének. A szeizmikus szelvényeken látott geometria és gravitációs magvevővel nyert üledékek adatainak összevetéséből Campania partközeli kontinentális talapzatán számos olyan üledékes és vulkáni szerkezet, valamint hidrotermális jelenség került leképezésre, melyek a legutolsó glaciális maximum (kb. 18000 év) óta keletkeztek.

A Pozzuoli-öbölben mért Seistec szelvények jól mutatják a beomlott kaldera gyưrús vetőjét, a kb. 15 ezer éves Nápolyi Sárga Tufa (NYT) lerakódáshoz vezető kitöréskor felújuló boltozatot, és alátámasztják a deformáció későnegyedidőszaki korára és stílusára vonatkozó hipotéziseket. A szeizmikus szelvényeken látható a NYT rétegeinek töréses szerkezete, valamint hidrotermális fluidum-feláramlások és vulkáni/szubvulkáni intrúziók a gyưrűs vetők mentén.

A Somma-Vezúv rétegvulkán előterében a kontinentális talapzat felett mért szeizmikus szelvények leképezték a Vezúv i.sz. 79-es kitörésekor Herculaneum városát elpusztító piroklaszt-ár tengervízbe érésekor keletkező, gravitációsan összeomló homokhullámok szerkezetét is

A Somma-Vezúv és a Pozzuoli-öböl közti, buckás felszínú Banco della Montagna területén mért szelvények és fúrómagok vulkanoklasztos diapírok sorát tárták fel. Ezeket a konszolidálatlan horzsakőbő́l álló testeket a fluidumfeláramlás és aktív kigázosodás hatására kialakult mélybeli túlnyomás hozta fel a tengerfenékre.

Tárgyszavak: nagy felbontású egycsatornás szeizmikus szelvényezés, Campania vulkanizmusa, vulkáni törmelékes üledék, Flegreimezók, kaldera vetó, Somma-Vezúv, késó-negyedidőszak, Nápolyi-öböl

Abstract

Very high-resolution, single channel (IKB-Seistec ${ }^{\mathrm{TM}}$ ) reflection seizmic profiles acquired in the Bay of Naples, complemented with geological and geophysical data from the literature, provide unprecedented, superb seismic imaging of the latest Pleistocene-Holocene stratigraphic architecture of the submerged sectors Campi Flegrei and Somma-Vesuvius volcanic districts. Seismic profiles were calibrated by gravity core data and document a range of depositional systems, volcanic structures and hydrothermal features that evolved after the onset of the Last Glacial Maximum ( $18 \mathrm{ka} \mathrm{BP})$ over the continental shelf on the Campania coastal zone.

Seistec profiles from the Pozzuoli Bay yield high-resolution images of the shallow structure of the collapse caldera-ring fault - resurgent dome system associated with the eruption of the Neapolitan Yellow Tuff (NYT) (ca 15 ka) and support a working hypothesis to assess the timing and the styles of deformation of the NYT resurgent structure throughout the latest Quaternary. Seismic images also revealed the nature of the fragile deformation of strata along the NYT ring fault system and the occurrence of hydrothermal fluids and volcanic/subvolcanic intrusions ascending along the ring fault zone.

Seismic data acquired over the continental shelf off the Somma-Vesuvius stratovolcano, display evidence of gravitational instability of wavy bedforms representing the submarine prosecution of pyroclastic flows originated from the Vesuvius during the eruption that destroyed the Roman city of Herculaneum in $79 \mathrm{CE}$.

At the Banco della Montagna, a hummocky seafloor knoll located between the Somma-Vesuvius and the Pozzuoli Bay, seismic profiles and gravity core data revealed the occurrence of a field of volcaniclastic diapirs formed by the dragging and rising up of unconsolidated pumice, as a consequence of fluid overpressure at depth associated with active degassing and fluid venting at the seafloor.

Keywords: high-resolution single channel reflection seismics, Campania Volcanism, Volcaniclastic settings, Campi Flegrei, Caldera ring fault, Somma-Vesuvius, Late Quaternary, Bay of Naples 


\section{Introduction}

Traditionally, high-resolution marine reflection seismic data have been acquired using single-channel analogue methods, for general stratigraphic purposes, geotechnical applications and prospecting for placer deposits, on relatively small areas (a few $\mathrm{km}^{2}$ ) (e.g. MCGEe 1995, 2000; SCHREILECHNER \& EICHKITZ 2015 and references therein).

During the last decades, the demand for digital seismic reflection profiling techniques suitable for producing extensive, high horizontal and vertical resolution datasets, has progressively increased (e.g. LERICOLAIS et al. 1990, MOSHER \& SimpKIN 1999). Innovative system design, such as the IKB-Seistec system utilising a boomer source and a hydrophone group shielded by a focusing cone (SIMPKIN \& DAVIS 1993), have proven to be able to increase signal/noise ratio of boomer-based systems providing exceptional combination of resolution and penetration.

The acquisition of ultra-high-resolution datasets has resulted in a number case-studies where seismic imaging has been used to support outcrop-scale seismic and sequence stratigraphic interpretation of both marine and continental environments (e.g. AITKEN \& Howell 1996; SACCHI et al. 1998, 1999; SCHWAB et al. 2003; ZeCChin et al. 2008; REIJENSTEIN et al. 2011; CserkésZ-NAGY et al. 2012; ZeCChIN \& CATUNEANU 2013; VISNOVITZ et al. 2015a, b; GARCíA et al. 2016).

In recent years, high resolution seismic profiling has been also applied to the study of marine volcanic systems, aiming at detecting volcanism-induced products and processes at the seafloor (PlANKe et al. 2000, ABDELMALAK et al. 2016, PlanKe et al. 2017, ANGKASA et al. 2017, BisChOFF et al. 2017) and analysing mixed siliciclastic-volcaniclastic depositional systems (e.g. LuCCHI et al. 2004; SACCHI et al. 2005; LuCCHI et al. 2007, 2009; SACCHI et al. 2009, 2014; ROMAGNOLI et al. 2018).

In this study, we reconstruct the stratigraphic architecture of a series of volcanic/hydrothermal structures and depositional units that formed offshore Campi Flegrei and Somma-Vesuvius (Bay of Naples) during the latest Pleistocene-Holocene. The research work was based on the use of ultra-high-resolution (IKB-Seistec) reflection seismics integrated high-resolution swath bathymetry, and gravity core data. Main targets of seismic imaging and interpretation included: 1) the stratigraphic architecture of the caldera collapse-resurgent structure associated with the eruption of the Neapolitan Yellow Tuff (NYT) of Campi Flegrei; 2) Secondary sedimentary structures within pyroclastic flow deposits along the slope of Somma-Vesuvius complex; and 3) Structure and composition of the volcaniclastic diapirs field of the Banco della Montagna.

Campi Flegrei and Somma-Vesuvius are active volcanic districts of the Eastern Tyrrhenian Margin, and among the most investigated areas of the Mediterranean Region (SANTACROCE et al. 2008, ConTiCelli et al. 2010). However, most of our understanding of volcanic rocks and structures of the Campania coastal zone derived so far from geological and geophysical studies whereas submarine volcanic pro- ducts and processes off the Bay of Naples are so far much less understood.

The acquisition of Seistec reflection seismic survey in the Bay of Naples provides an exceptional opportunity to analyse the interaction between a primary volcanic system and its sedimentary environment. High-resolution seismic stratigraphy may also has relevance for understanding the source to sink component of sedimentary processes and unravel the correlation among stratigraphic units (SCHNEIDER et al. 2001, SEGSCHNEIDER et al. 2002, SCHNEIDER et al. 2004, MANVILLE et al. 2009, NÉMETH et al. 2009, MARTí et al. 2018, NÉmeth \& PALmer 2018, LuCChi 2019).

Explosive volcanism produced large volumes of volcaniclastic sediments over the Campania coastal region, including pyroclastic air-fall deposits and flow/surge deposits that have been rapidly delivered to sites of deposition, also causing remarkable lateral facies changes as a result of seaward transformation of pyroclastic flows entering the seawater (e.g. Le Friant et al. 2009, Trofimovs et al. 2012, JUTZELER et al. 2017).

Due to the commonly high preservation potential of the marine volcaniclastic record (e.g. LE FRIANT et al. 2009, DI CAPUA \& GROPPELLi 2018), the area of the Bay of Naples documents key examples for a range of volcanic/hydrothermal features, characterised by significant magma-water interaction, and their depositional environments. The results of this research work provide a contribution to assess natural hazards (e.g. volcanism, bradyseism, seismicity and tsunamis) off the densely populated region of the Campania margin.

\section{Geological setting}

The Somma-Vesuvius stratovolcano and the Campi Flegrei Volcanic District are located in the western part of the Campanian Plain, a sector of Quaternary extension and subsidence on the Tyrrhenian margin of the Southern Apennines orogen (Figure 1; SCANDONE et al. 1991). The orogen was assembled during Miocene-Early Pleistocene E to NEdirected compression related to subduction and roll-back of the Adriatic crust, a promontory of the ancient north African continental margin (Doglioni 1991). Contraction was followed by coaxial extension on NW-SE trending normal faults associated to stretching and formation of the Tyrrhenian Sea in the back-arc sector of the southern Apennines (HoRvátH et al. 1981, MALINVERnO \& RYAn 1986, PATACCA et al. 1990, Oldow et al. 1993, FACCENNA et al. 1997, JoLIVET et al. 2009). In the Tyrrhenian margin and the Campania Plain, extension was also accommodated by E-W to NE-SW striking, listricshaped normal faults which trend transversal to the chain (SACCHI et al. 1994, FerRanti et al. 1996, Milia 1999, Figure 1). Displacement on these latter normal faults caused dominoblock faulting and growth of up to $\sim 3.5 \mathrm{~km}$ deep extensional basins (e.g. the Gulf of Naples) segmented by buried ridges (e.g. Sorrento Peninsula).

Volcanic processes on the Tyrrhenian margin of the Campania Apennines are related to a combination of sub- 


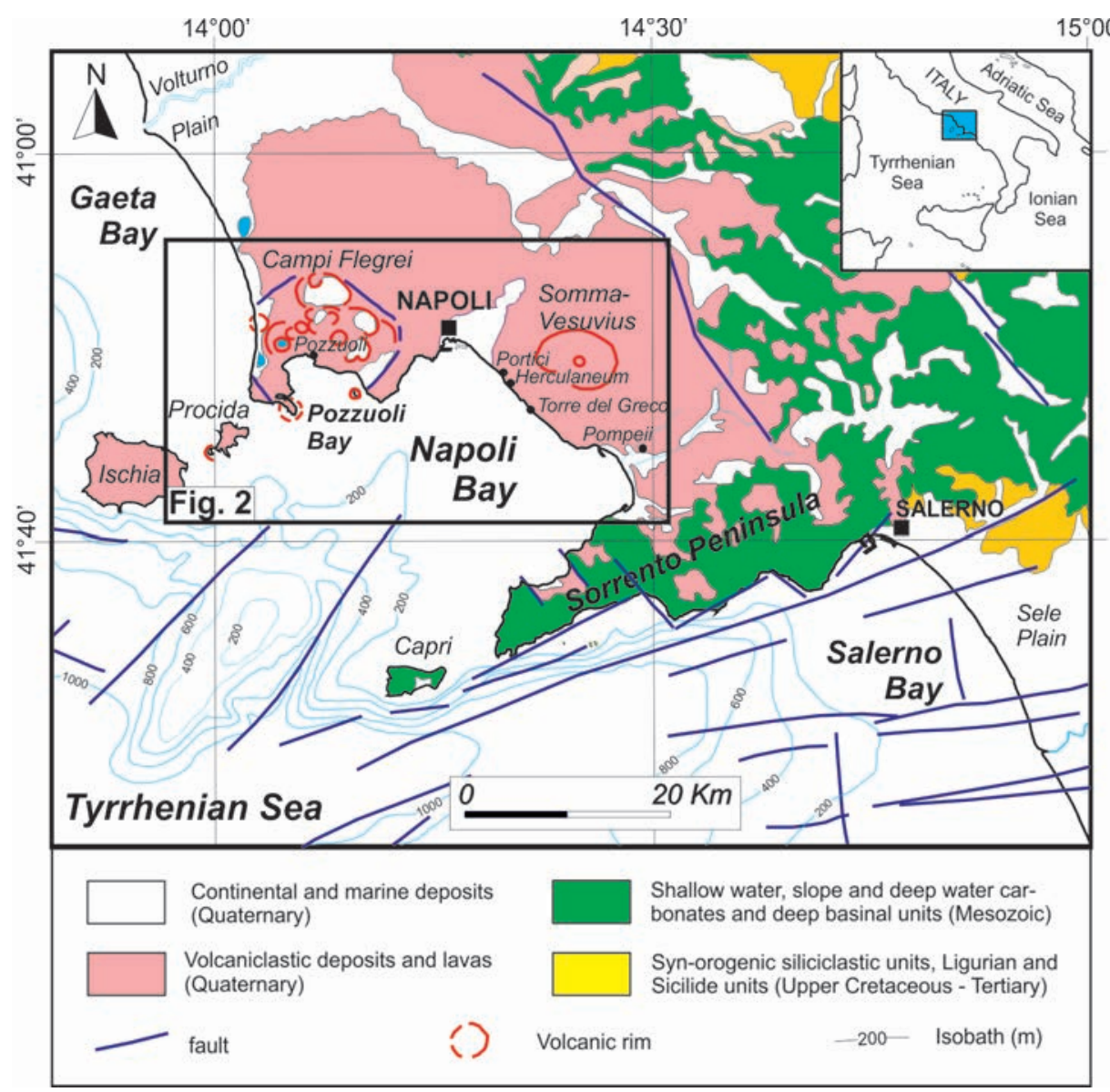

Figure 1. Geologic sketch-map of the Eastern Tyrrhenian margin of Campania Apennines with location of the study area

1. ábra. A Kelet-Tirrén menti Campaniai-Appenninek földtani térképvázlata a kutatási terület megjelölésével

duction roll-back and back-arc extension, which led to formation of potassic (shoshonitic) and highly silica undersaturated (ultrapotassic) volcanic rock suites dated at least 0.8 Ma BP (PECCERILlo 2005). Onset of volcanism is dated at $0.6 \mathrm{Ma}$ in the northern part of the Campania Plain (CONTICELLI et al. 2010 and references therein), and since $\sim 150 \mathrm{ka}$ it led to the formation of the Campi Flegrei Volcanic District (Rosi \& Sbrana, 1987, Barberi et al. 1991) and Mt. SommaVesuvius stratovolcano (RolANDi 1998, SANTACROCE et al. 2008 and references therein) as well as of a number of submerged vents located in the Naples and Pozzuoli Bays (Figures 1-2). Magma upwelling and fluid emission are thought to be controlled by the interaction of NW-SE and NE-SW striking normal faults (ACOCELLA \& FUNICIELLO, 2006). Now buried volcanic activity is testified by borehole data and tephra layers in the Campania Plain (e.g. BROCCHINI et al. 2001, DE Vivo et al. 2001, InsingA et al. 2014).

\section{Campi Flegrei}

The Campi Flegrei District (Figures 2-3) is situated immediately west of Naples and includes the volcanic fields of Campi Flegrei (e.g. Di Vito et al. 1999, PAPPALARDO et al. 1999, SCARPATI \& PERROTTA 2012); Ischia island (e.g.
Cassignol \& Gillot, 1982, Vezzoli et al. 2009, Carlino et al. 2012, PAOLETti et al. 2013) and Procida island e.g. (DE Astis et al. 2004, PERrottA et al. 2010). The area has been active since at least $\sim 80 \mathrm{ka}$ BP (PAPPALARDO et al. 1999, SCARPATI et al. 2013) mostly with explosive eruptions.

The continental Campi Flegrei area is structurally dominated by a collapse caldera, associated with the eruption of the Neapolitan Yellow Tuff (NYT), a 30-50 km³ Dense Rock Equivalent (DRE) ignimbrite (e.g. COLE \& SCARPATI 1993) dated at $\sim 15 \mathrm{ka}$ (DEINO et al. 2004). The caldera is represented by a quasi-circular depression of $\sim 8 \mathrm{~km}$ in diameter which developed in the central sector of the Campi Flegrei, including the onshore area and part of Pozzuoli Bay (Figure 4) (Rosi \& SBRANA 1987; SCARPATI et al. 1993; OrSI et al. 1996; Florio et al. 1999; JudenHerC \& Zollo 2004; DE NATAle et al. 2006; Dello IACONO et al. 2009; SACCHI et al. 2009, 2014; STEINMANN et al. 2016, 2018). The NYT collapse was preceded by a high-magnitude $\left(150 \mathrm{~km}^{3} \mathrm{DRE}\right)$ eruption, namely the Campania Ignimbrite (CI; 39 ka) which was originated during a larger caldera collapse at Campi Flegrei (Rosi \& SBrana 1987, Orsi et al. 1992, Wohletz et al. 1995, DEINO et al. 2004, FEDELE et al. 2016) or alternatively by fissural events occurring in the Campania Plain (DE VIVo et al. 2001, Rolandi et al. 2003, De NATALE et al. 2016). 


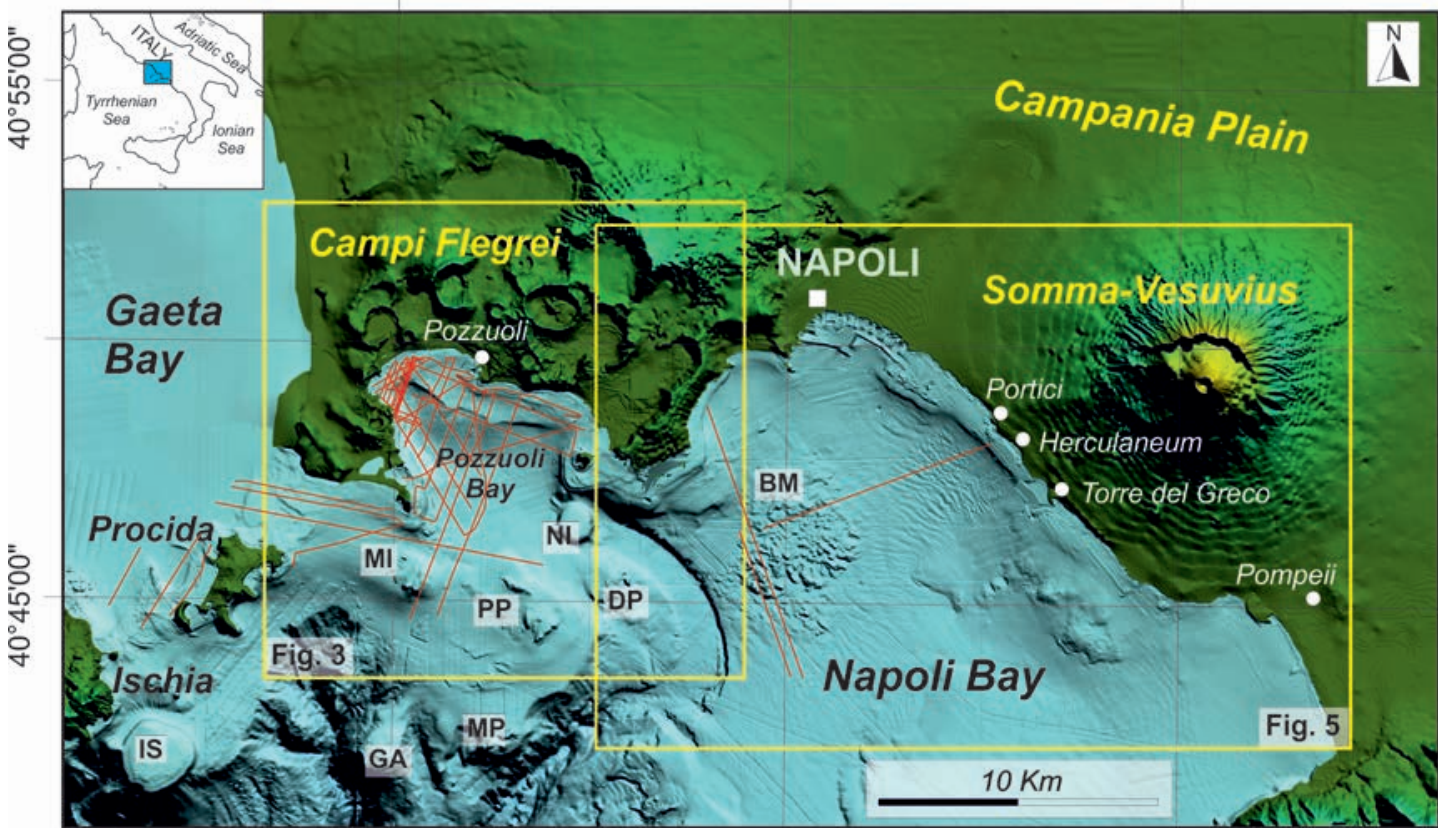

Figure 2. Digital Terrain Model (DTM) of the Campania coastal zone with location of the acquired IKB-Seistec seismic grid and major volcanic morphostructures in the Bay of Naples (GA = Gaia bank, MP Mariapia bank, PP = Penta Palummo bank, IS = Ischia bank, MI = Miseno bank, NI = Nisida bank, DP = M. Dolce-Pampano bank, BM = Banco della Montagna). Frames of Figures 3 and 5 are also indicated 2. ábra. Campania partmenti területének digitális terepmodellje az IKB-Seistec szeizmikus mérési hálózat, valamint a Nápolyi-öböl jelentösebb vulkáni szerkezeteinek feltüntetésével (GA = Gaia pad, MP = Mariapia pad, $P P=$ Penta Palummo pad, IS = Ischia pad, MI = Miseno pad, $N I=$ Nisida pad, DP=M. Dolce-Pampano pad, BM = Banco della Montagna). Az ábrán feltüntettük a 3. és 5. ábra kivágatát is

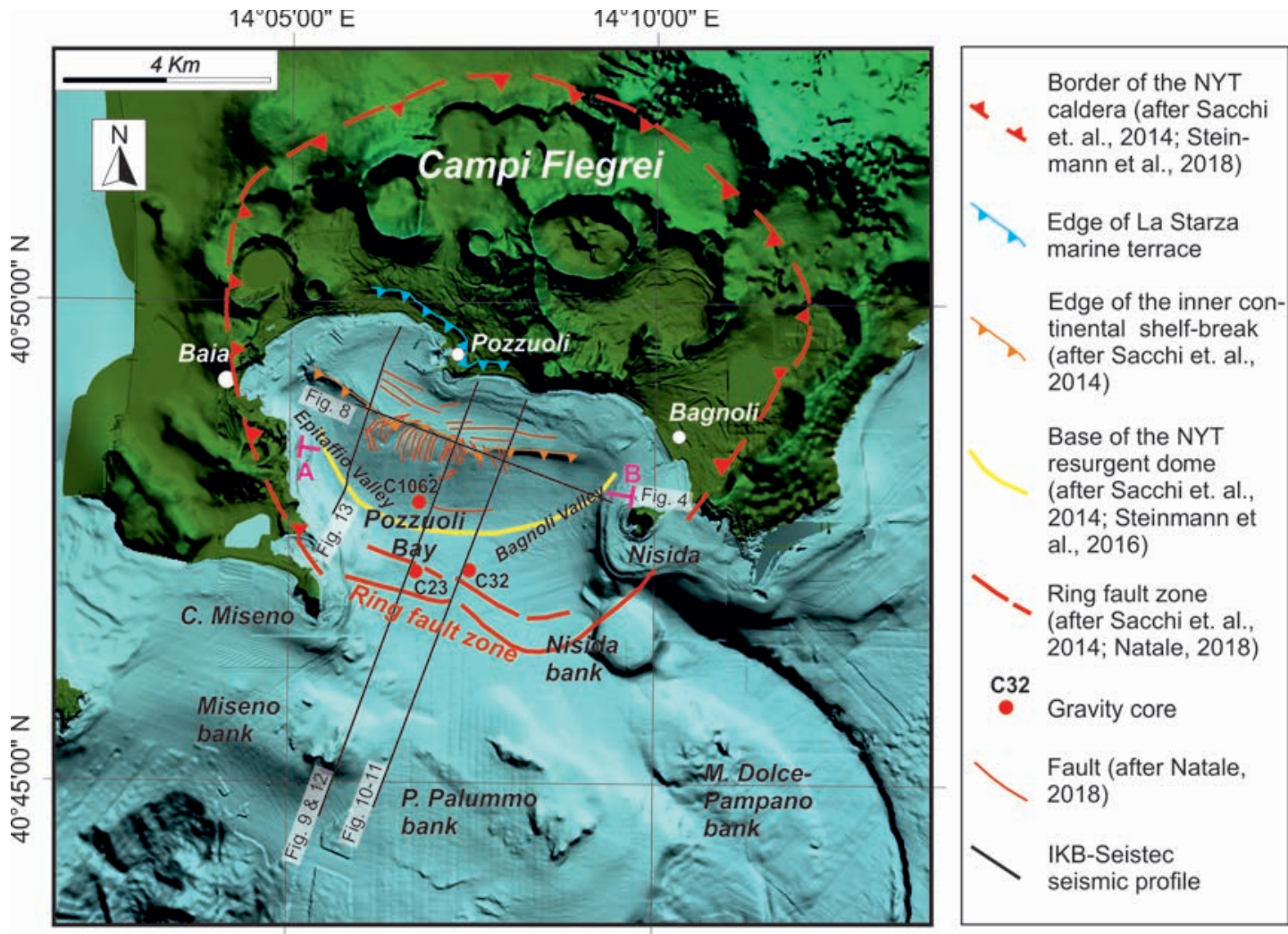

Figure 3. DTM of the Campi Flegrei coastal area with location of major morphostructures off the Pozzuoli Bay. Traces of cartoon section A-B (Figure 4) and seismic profiles illustrated in Figures 8-13 are also shown

3. ábra. A Campi Flegrei partmenti terület digitális terepmodellje a Pozzuoli-öböl föbb morfológiai elemeinek feltüntetésével. A 4. ábrán bemutatott A-B szelvény, valamint a 8-13. ábrákon szereplö szeizmikus szelvények helyszínét az ábrán szintén feltüntettük 
Post-NYT activity (last $15 \mathrm{ky}$ ) was characterised by hydromagmatic activity associated with the formation of several small vents and several monogenetic volcanoes including tuff rings, tuff cones, as well as a few cinder cones and lava domes occurred inside the caldera at 3.8-4 ka (DI VitA et al. 1999, Insinga et al. 2006, Fedele et al. 2011, DI Renzo et al. 2011, SACCHI et al. 2014). The Monte Nuovo eruption in $1538 \mathrm{CE}$ was the last event, which occurred after 100 years of ground deformation (DE VITO et al. 1999, ISAIA et al. 2004, D'Oriano et al. 2005, BelluCCI et al. 2006).

The post-collapse evolution was marked by development of a resurgent dome in the central part of the caldera including the Gulf of Pozzuoli (Figure 4) (ORSI et al. 1999; ACOCELla 2010; SACCHI et al. 2014; STEINMANn et al. 2016, 2018; MARTURANO et al. 2018). Dome resurgence resulted in the emersion of a marine deposit, the so-called La Starza terrace, which is presently exposed up to $\sim 30 \mathrm{~m}$ above sea level (Cinque et al. 1985, Di Vito et al. 1999, Marturano et al. 2018). During Late Pleistocene-Holocene the large amount of volcaniclastic material produced at Campi Flegrei is rapidly delivered into the Pozzuoli Bay in a source-to-sink system where primary pyroclastic deposits are intimately interbedded with marine siliciclastic sediments and reworked volcaniclastic derivied from the dismantling of coastal vents (e.g. SACCHI et al. 2014).

Caldera unrest during the last decades is testified by extensive hydrothermalism, accompanied by two major episodes (1970-71 and 1982-84) of shallow seismicity and ground/seafloor deformation originating uplift up to $3.5 \mathrm{~m}$ in 15 years, with maximum rates of $100 \mathrm{~cm} /$ year in the period 1983-1984 (BERRINO et al. 1984, DVORAK \& BERRINO 1991, De Natale et al. 2001, BatTaglia et al. 2006, BodnaR et al. 2007, LimA et al. 2009).

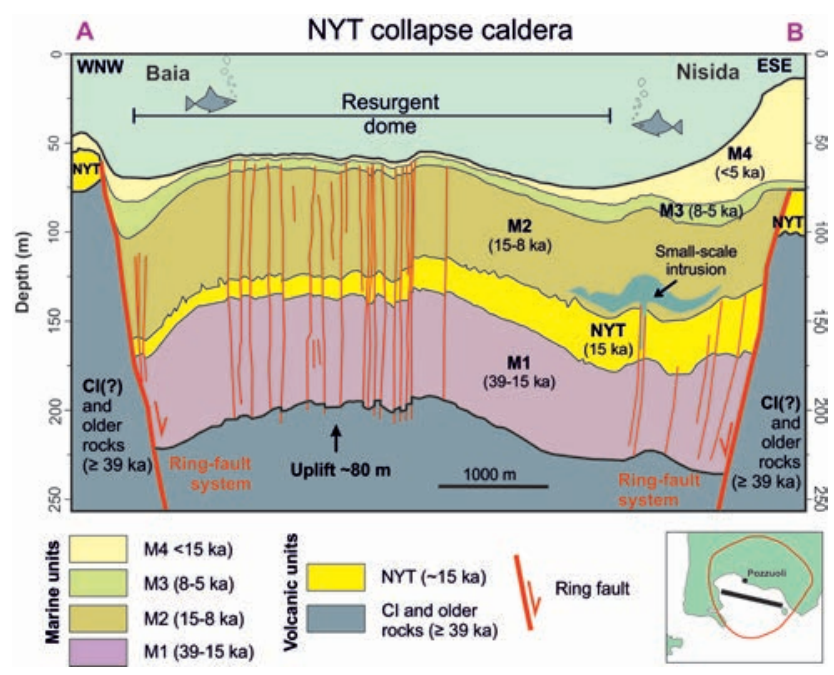

Figure 4. Cartoon section showing the shallow structure of the Neapolitan Yellow Tuff (NYT) collapse-resurgent caldera as imaged by offshore seismic exploration. Interpretation of seismic stratigraphic units is modified after STEINMANN et al. (2016). Not to scale

4. ábra. Tengeri szeizmikus mérések alapján készitett szelvényvázlat a Nápolyi Sárga Tufa (NYT) kaldera szerkezetéról. A szeizmikus sztratigráfia értelmezés STEINMANN et al. 2016 alapján. Méretarány nélkül

\section{Somma-Vesuvius}

The Somma-Vesuvius is a stratovolcano with alternating pyroclastic and lava flow deposits, composed by an older disrupted edifice (Mt. Somma) and an intra-caldera cone (Mt. Vesuvius; Figures 2 and 5). The Mt. Somma volcano was formed after the CI eruption ( $39 \mathrm{ka}$ ), and was dismantled by at least 6 following plinian events, among which the eruptions of Avellino ( $3.9 \mathrm{cal} \mathrm{ka}$; SEvinK et al. 2011) and of 79 CE that destroyed the Roman cities of Herculaneum, Pompeii and Stabiae. These events are well characterised in the proximal marine setting since they are associated to large amounts of pyroclastic materials intercalated in the Late Holocene sequence of the Bay of Naples including extensive fall, flow and surge deposits along with large volumes of volcaniclastics related to volcano flank collapses (e.g. MiLIA et al. 2003, SANTACROCE et al. 2008 and references therein)

The following interplinian activity, manifested through 17 eruptive Vesuvian cycles, terminated with the 1944 CE eruption, and was accompanied by the formation of some eccentric cones and lava domes (e.g., SANTACROCE 1987, Rosi et al. 1993, Principe et al. 2004, Di Renzo et al. 2007, Cioni et al. 2008, SANTACROCE et al. 2008), whose products are also found in the distal marine sector (PAOLETTI et al. 2016).

\section{Data and methods}

This study is based on the interpretation of an ultra-highresolution (IKB-Seistec), single-channel reflection seismic survey acquired in November of 2013 on the continental shelf of the Bay of Naples, between Procida Island and the SommaVesuvius offshore (Figures 2, 3 and 5). Seistec profiles were integrated by geophysical and geological datasets, acquired at various stages between 2000 and 2014, including multibeam bathymetry and sedimentological analysis of gravity cores.

\section{IKB-Seistec data acquisition and processing}

The seismic dataset presented in this study includes a grid of more than $100 \mathrm{~km}$ of profiles acquired using the IKBSeistec profiler (Figures 2, 3 and 5). This single channel reflection seismic system has been designed specifically for collecting very high-resolution data in shallow water environments, but it can also be used in water depths $>200 \mathrm{~m}$ (SimpKIN \& DAVIS 1993, Mosher \& SimpKin 1999). The Seistec system comprises a $2.5 \mathrm{~m}$ long catamaran supporting both the boomer source and the receiver (Figure 6). The seizmic source is an IKB model B3 wide band electrodynamic "boomer" producing a single positive peak pressure impulse with a primary pulse width of $120 \mathrm{~ms}$. The receiving system is a line-in-cone receiver located adjacent to the boomer plate $(70 \mathrm{~cm})$. The source emits useful frequencies in the range $1-20 \mathrm{kHz}$ and, thanks to this wide frequency band, allows resolution of reflectors spaced 20 $\mathrm{cm}$ apart. Penetration can exceed $100 \mathrm{~m}$ in soft deep-water sediments. 


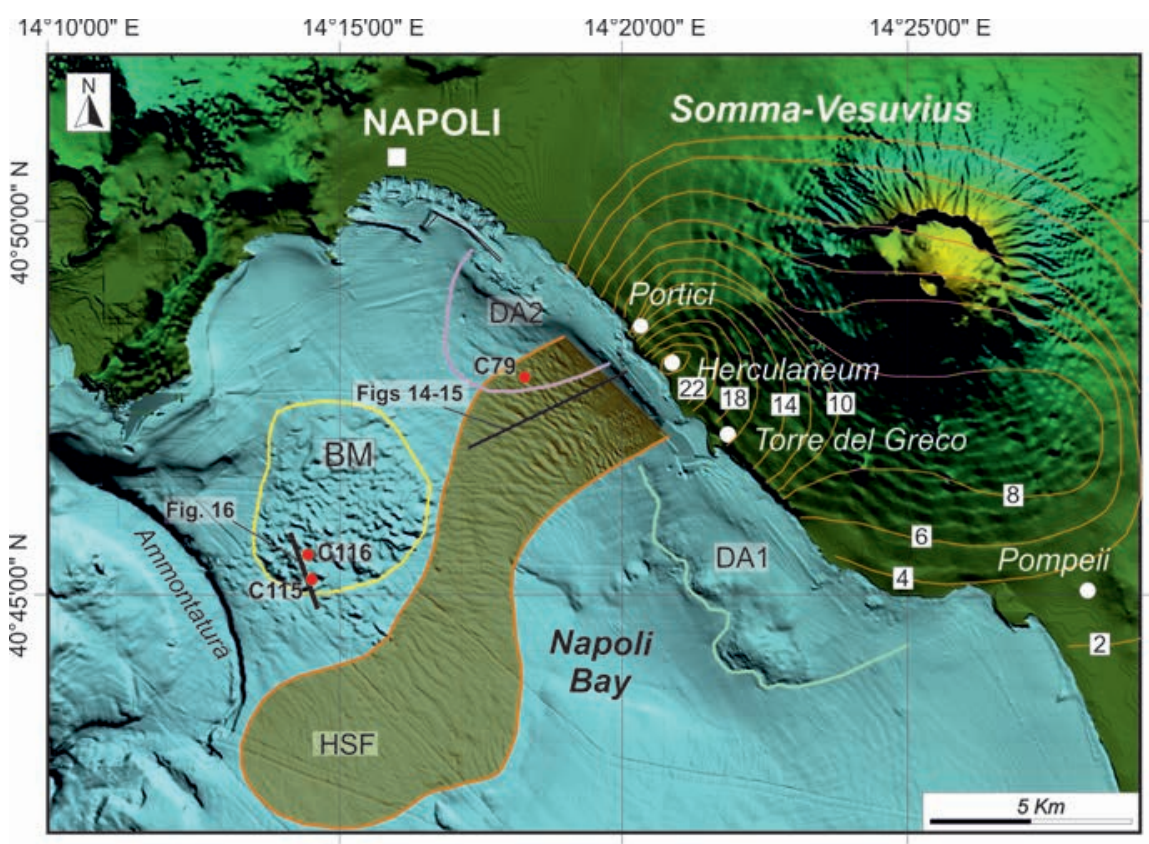

Isopachs ( $m$ ) of the Vesuvius AD 79 pyro-
clastic flow deposits (from Lirer et al. 1997)

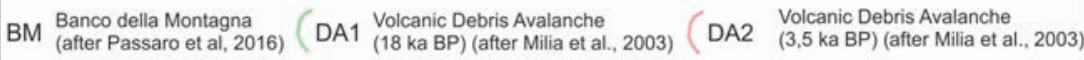

Figure 5. DTM of the Somma-Vesuvius coastal area with location of the major volcanic features off the Eastern sector of the Bay of Naples. Isopachs (m) of the Vesuvius 79 CE pyroclastic flow deposits onshore are from LIRER et al. (1997). Location of profiles and gravity cores shown in Figures 14-16 is also indicated

5. ábra. A Vezúv tengerparti környezetének digitális terepmodellje a Nápolyiöböl keleti részének föbb vulkáni elemeivel. A Vezúv 79-es kitörésének szárazföldi piroklaszt rétegvastagságát LIRER et al. (1997) alapján ábrázoltuk. A 14. és 16. ábrákon bemutatott szelvények és gravitációs magvételi helyeket szintén feltüntettük
During the survey, on board a small boat at a speed of about 3 knots, a STEP power supply was used with a power of $150 \mathrm{~J}$ and a shooting rate of 4-6 shots/s. The position during navigation was determined by a differential GPS directly mounted at the CDP point of the IKB-Seistec profiler. The exceptional time resolution and the fixed source-receiver geometry of the Seistec profiling system, together with its high sub-bottom penetration, allow for a quantitative analysis of the different seismicsignature shapes and geometries and signal amplitudes.

Processing and interpretation of Seistec data was performed using (ProMAX®), and Geo-Suite AllWorks@ software packages). Signal penetration was found to exceed $200 \mathrm{~ms}$ (TWT). Vertical resolution reached up to $0.1 \mathrm{~m}$ near the seafloor.

Time to depth conversion of the vertical scale for the seismic records was obtained by correlation between stratigraphic units and inferred seismic velocities on the basis of seismic facies analysis and lithostratigraphy (Rosi \& SBRANA 1987; Di ViTO et al. 1999; SACCHI et al. 2014; STEINMANN
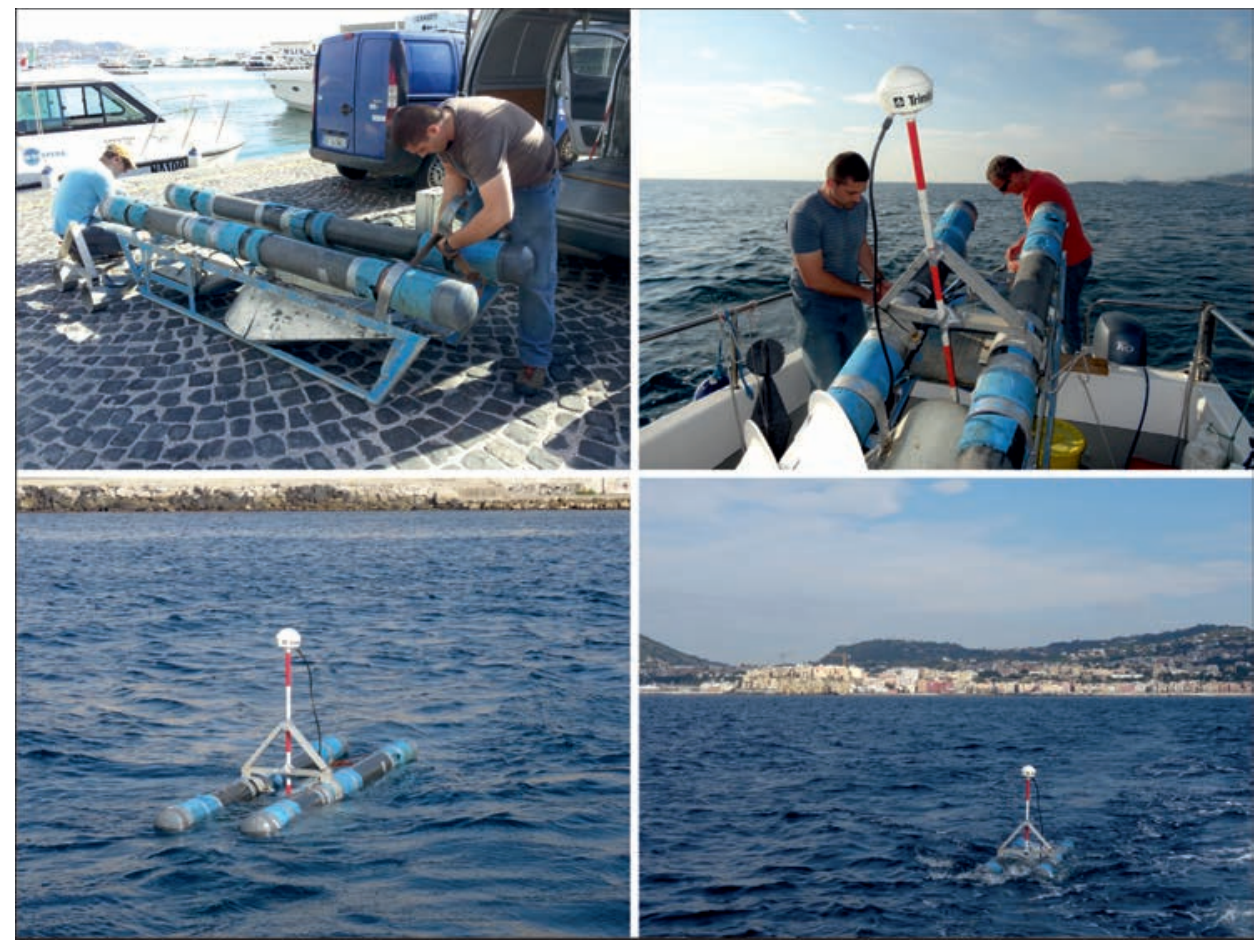

Figure 6. Set up of the IKB-Seistec boomer system and seismic profiling operations offshore Pozzuoli, Bay of Naples 6. ábra. Az IKB-Seistec szeizmikus mérôrendszer mérésre történö elókészitése és szeizmikus mérés Pozzuoli előterében a Nápolyi-öbölben 
et al. 2016, 2018). A minimum average seismic velocity of $1600 \mathrm{~m} / \mathrm{s}$ has been assigned to the shallowest stratigraphic levels, whereas a maximum velocity between 1650 and 1700 $\mathrm{mm} / \mathrm{s}$ has been assumed for the deepest horizons. Depthconverted sections were plotted with vertical exaggeration of $6-8 \times$, in order to enhance the visibility of low-angle stratigraphic boundaries and better display the internal architecture of stratigraphic units.

\section{Multibeam bathymetry}

The multibeam bathymetric survey of the Bay of Naples has been mostly acquired between 2000 and 2014, using a Simrad EM 710 multibeam echosounder (Kongsberg@inc.). Processing of MBES data was carried out with PDS2000 software following the International Hydrographic Organization standards (IHO 2008). Processing comprised the removal of navigation errors, noise reduction (i.e. de-spiking), removal of poor quality beams, and tidal and sound velocity corrections (e.g. DE AlTERIIS et al. 2003). The final DTM derived from the MBES depth interval $0950 \mathrm{~m}$ b.s.l., covers an area of $\sim 700 \mathrm{~km}^{2}$ with a cell size of $5 \mathrm{~m}$ (Figures $2-3$ and 5). Topographic data were obtained from the official topographic grid of the Military Institute for Geography (IGM; $20 \mathrm{~m}$ grid cell), acquired between 1985 and 1990 by aerial photogrammetry (AMADIO 1992).

\section{Gravity coring and laboratory analysis}

Stratigraphic calibration of high-resolution, single channel seismic records was assisted by the integrated stratigraphic analysis of gravity cores C23, C32, C1016, C79, C115 and C116 (Table 1 and Figure 7) as a selection out of a large number of gravity cores, collected in the Bay of Naples over the last decades (INSINGA 2003; INSINGA et al. 2008; D'ARGENIO et al. 2004; SACCHI et al. 2005, 2009, 2014; MoLISSO et al. 2010). The study included microscope observation on selected samples of sieved wet sediment (63- $\mu \mathrm{m}$ and $30-\mu \mathrm{m}$ sieves) collected from the core logs and the recognition of major lithofacies associations, sedimentary structures,

Table I. List of marine gravity cores used for geological calibration of seismic stratigraphic units derived by IKBSeistec data

I. táblázat. Az IKB-Seistec reflexiós szeizmikus szelvények kalibrálásához felhasznált gravitációs magminták listája

\begin{tabular}{cccccl}
\hline Gravity Core & $\begin{array}{c}\text { Latitude } \\
\mathrm{N}\end{array}$ & $\begin{array}{c}\text { Longitude } \\
\mathrm{E}\end{array}$ & $\begin{array}{c}\text { Water depth } \\
(\mathrm{m})\end{array}$ & $\begin{array}{c}\text { Core lenght } \\
(\mathrm{cm})\end{array}$ & \multicolumn{1}{c}{ Reference } \\
\hline 23 & $40^{\circ} 47^{\prime} 10^{\prime \prime}$ & $14^{\circ} 06^{\prime} 45^{\prime \prime}$ & 103.0 & 490 & SACCHI et al. (2014) \\
32 & $40^{\circ} 47^{\prime} 10^{\prime \prime}$ & $14^{\circ} 07^{\prime} 27^{\prime \prime}$ & 103.0 & 382 & SACCHI et al. (2014) \\
C 1062 & $40^{\circ} 47^{\prime} 54^{\prime \prime}$ & $14^{\circ} 06^{\prime} 48^{\prime \prime}$ & 90.6 & 265 & SACCHI et al. (2014) \\
C 79 & $40^{\circ} 48^{\prime} 08^{\prime \prime}$ & $14^{\circ} 18^{\prime} 33^{\prime \prime}$ & 89.0 & 544 & MiLIA et.al. (2008) \\
C 116 & $40^{\circ} 45^{\prime} 45^{\prime \prime}$ & $14^{\circ} 14^{\prime} 18^{\prime \prime}$ & 131.7 & 571 & INSINGA (2003); This work \\
C 115 & $40^{\circ} 45^{\prime} 28^{\prime \prime}$ & $14^{\circ} 14^{\prime} 19^{\prime \prime}$ & 136.0 & 540 & INSINGA (2003); This work \\
\hline
\end{tabular}

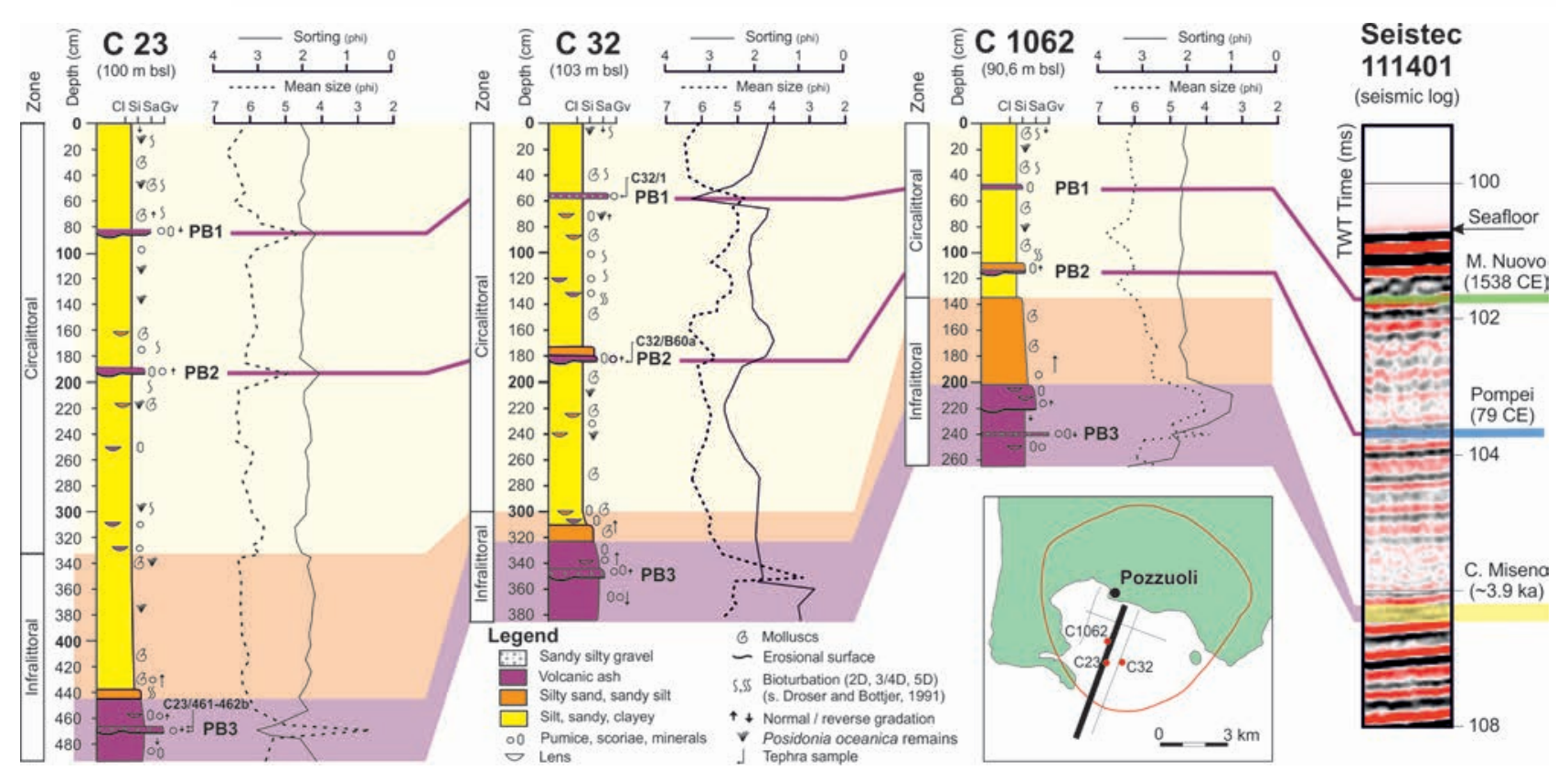

Figure 7. Calibration of shallower seismic (IKB-Seistec) reflectors by integrated stratigraphy of gravity core data from the Pozzuoli Bay (after SACCHI et al. 2014, MARINO 2018)

7. ábra. Kis mélységü szeizmikus reflexiók kalibrációja a gravitációs magvevök egységes sztratigráfiai adatai alapján a Pozzuoli-öbölben (SACCHI et al. 2014 és MARINo 2018 alapján) 
palaeontological analysis, and grain-size analysis by laser diffractometry (Sympatec). Identification and ecological analysis of foraminifers and molluscs were carried out following PÉRÈs \& PiCARD (1964), LOEBLICH \& TAPPAN (1988) and Sgarrella \& Moncharmont Zei (1993).

Volcanic deposits in core C115 were sampled, wet sieved and observed at the optical microscope. Glass concentrates (pumice and glass shards) were selected, rinsed in distilled water with acetic acid to remove carbonate incrustations and, finally, they were cleaned with an ultrasonic probe (INSINGA 2003). Major and trace-element content was obtained on pressed powder pellets using a Philips PW1400 X-Ray fluorescence spectrometer, at DiSTAR, Federico II University, Napoli, following procedures outlined in MeLLuso et al. (1997). The correlation of the analysed tephras with proximal deposits was based on the comparison with published data on both single glass shards and the rock matrix.

\section{Results}

\section{Seafloor morphology of the Bay of Naples}

The general physiography of the Bay of Naples is characterised by a wide continental shelf extending to water depths of 100-80 m (Figure 2). The shelf width varies from a maximum of about $20 \mathrm{~km}$ in the central part of the bay to about $2.5 \mathrm{~km}$ off the islands of Capri and Procida.

The occurrence of volcanic bedrock and/or volcaniclastic deposits has an influence in the morphology of the continental shelf-slope system of the Bay of Naples that displays relatively high slope angles $\left(\sim 1.0^{\circ}\right.$ on average on shelf areas and up to a maximum of $77^{\circ}$ on the upper continental slope).

The NW sector $\left(\sim 110 \mathrm{~km}^{2}\right)$ is characterised by the inlet of Pozzuoli Bay, and very irregular seafloor morphology due to the occurrence of several volcanic banks, mostly south of the Capo Miseno-Nisida alignment (Milia 1999, 2010; MiLiA \& TORRENTE 2000, 2003; InSINGA et al. 2006; SACCHI et al. 2009, 2014; Di RENZO et al. 2011; FEDELE et al. 2011; STEINMANN et al. 2016, 2018; PASSARO et al. 2018; Figures 2-3).

A remarkable morphological feature of the inner sector of the Pozzuoli Bay is represented by a pronounced break in the profile of the inner continental shelf. This lineament is elongated in a WNW-ESE direction, ranging water depths from $\sim 25$ to $\sim 45 \mathrm{~m}$ b.s.1. towards ESE (Figure 3). A slightly convex-upward area, with average slope of less than $3^{\circ}$, connects the inner shelf break to the deeper part of the bay, where water depth reaches $\sim 115 \mathrm{~m}$. At the foot of the inner shelf slope, the transition between these domains occurs along a semi-circular depression extending in NNW-SSE (Epitaffio Valley) and NE-SW (Bagnoli Valley) directions (Figure 3).

In the north-eastern sector of the Bay of Naples (Figures 2 and 5), the continental shelf is relatively wide and covers an area of $\sim 380 \mathrm{~km}^{2}$. The seafloor morphology of this region is dominated by seaward sloping of the south-western flank of the Vesuvius, reaching into the shallow marine area. Here, the interaction between volcanism and sedimentary processes produced a variety of local seafloor morphologies including (Figure 5) wavy bedforms (MiLIA et al. 2008, PASSARO et al. 2018) and buried debris avalanches (DA1 and DA2; PASSARO et al. 2018).

Offshore Herculaneum, a $13 \mathrm{~km}$ long and 2-3 km wide region characterised by the occurrence of wavy bedforms (Herculaneum Sand wave Field) with maximum amplitude of $10 \mathrm{~m}$ and wavelength of 200-250 m can be recognised (HSF in Figure 5). This is the morphologic expression of sediment waves displaying a seaward transition from chaotic morphology nearshore, to asymmetric wavy facies in the median zone, and smooth wavy stratification in distal areas (Milia et al. 2008).

In the area between the Pozzuoli Bay and Somma-Vesuvius, $\sim 8 \mathrm{~km}$ south of the town of Napoli morphobathymetric data reveal a prominent, dome-like morphology (Figure 5) represented by a quasi-circular hummocky seafloor relief, $\sim 5$ $\mathrm{km}$ in diameter (D'ARGENIO et al. 2004; PASSARO et al. 2014, 2016), known as Banco della Montagna (hereafter BM). The area extends over $25 \mathrm{~km}^{2}$, at water depths of $100-180 \mathrm{~m}$, and is characterised by an elevation of $\sim 20 \mathrm{~m}$ with respect to the surrounding seafloor. The hummocky morphology of BM is associated with the occurrence of 280 sub-circular to elliptical mounds, more than 650 cones, and 30 pockmarks (Figure 5), along with, a least 37 spots of gas emissions (PASSARO et al. 2016, 2108; VENTURA et al. 2018).

\section{Seismic expression of depositional environments and volcanic structures}

IKB-Seistec profiles were acquired in selected areas of the Bay of Naples with the aim of complementing previous intermediate to high resolution single channel and multichannel seismic surveys (SACCHI et al. 2014; STEINMANN et al. 2016, 2018). Seistec imaging and interpretation focused on relevant volcano-sedimentary features occurring in three main areas of the Bay of Naples: 1) the submerged sector of the Neapolitan Yellow Tuff (NYT) caldera offshore Pozzuoli (see later Figures 8-13); 2) sedimentary structures associated with pyroclastic flow deposits along the submerged slope of Somma-Vesuvius complex (see later Figures 14-15), and 3) the volcaniclastic diapirs field of the Banco della Montagna (see later Figure 16).

\section{Pozzuoli Bay}

Seistec profiles acquired in the Pozzuoli Bay were analysed to image the shallow structure and stratigraphic architecture of the Campi Flegrei (NYT) collapse-resurgent caldera (DI VITO et al. 1999; CAPUANO et al. 2013; SACCHI et al. 2014; STEINMANN et al. 2016, 2018). The WNW-ESE trending, 6.6-km long line Seistec 110801 extends from Baia to Nisida Island. The profile illustrates a cross section of large part of the collapse-resurgent structure, including the ring fault zone that is intersected along the eastern part of caldera margin (Figure 8).

The SSW-NNE trending profiles Seistec 111401 (8.5 km) and Seistec $111402(8.9 \mathrm{~km})$ provide seismic stratigraphic 


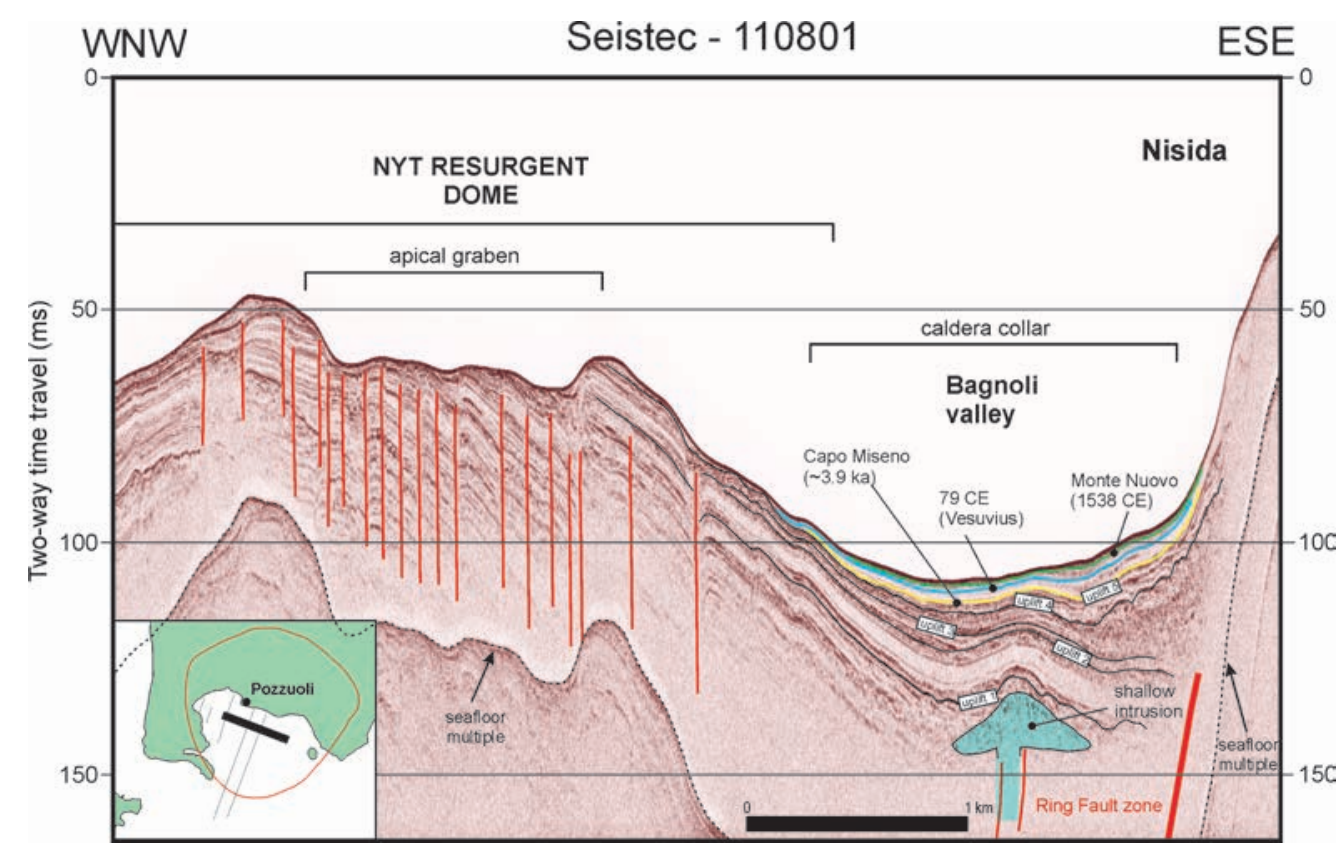

Figure 8. IKB-Seistec profile 110801 and its interpretation. Note the antiformal structure of the NYT caldera resurgent dome and brittle deformation at the summit of the resurgence (apical graben), as well as the shallow magmatic intrusion along the ring fault zone (Bagnoli Laccolith; SACCHI et al. 2014, NATALE 2018). Correlation of tephra layers associated with the eruptions of M. Nuovo (1538 CE) Vesuvius-Pompeii (79 CE) and C. Miseno ( 3.9 ka) are calibrated by gravity core data (Figure 7). Unconformities denoted as Uplift 1-5 are interpreted as the result of distinct phases of deformation and uplift of the resurgent structure during the last $\sim 12-5 \mathrm{ka}$

8. ábra. 110801 IKB-Seistec szelvény értelmezése. Jól látható a NYT kaldera szerkezetének kiemelt kupolája és a töréses szerkezetek a kiemelt helyzetü árkos szerkezetben (apical graben), valamint a kis mélységü, vetö menti magmás intrúzió (Bagnoli Laccolith, SACCHI et al. 2014, NATALE 2018). A M. Nuovo (1538), Vezúv-Pompei (79) és C. Miseno ( 3,9 ka) kitöréseihez kapcsolódó tefra rétegek korrelációja a gravitációs magminták adataival kalibráltak. (7. ábra). Az Uplift 1-5-el jelölt unkonformitások az elmúlt 5-12 ezer év során történt deformációk és kiemelkedések egyes fázisait jelölik

sections, roughly perpendicular to profile Seis-110801 from the outer continental shelf of the Bay in the South, up to the coastal shallow waters offshore Pozzuoli in the North. Both these profiles cross the southern flank of the NYT resurgent dome and the ring fault-caldera border structure along with the morphostructural high represented by the alignment of Penta Palummo (PP) and Miseno (MS) banks (Figures 3 and 9-10). Calibration of seismic profiles with gravity cores C23, C32 and $\mathrm{C} 1016$ (Figure 7) provides age control of the uppermost reflectors based on the correlation of three tephra layers namely corresponding, from top to bottom, to the products of M. Nuovo (1538 CE), Vesuvius-Pompeii (79 CE) and Capo Miseno ( 3.9 cal ka BP; SACCHI et al. 2014).

Seismic interpretation suggests that the thickness of the caldera fill is in the order of 60-80 m within the Pozzuoli Bay (Figures 8-10). The inner caldera resurgent dome is imaged as an antiformal structure covering an offshore area of $\sim 9 \mathrm{~km}^{2}$ with a diameter of $\sim 5 \mathrm{~km}$, associated with a maximum uplift of at least $\sim 120 \mathrm{~m}$ (SACCHI et al. 2014, SteInMANN et al. 2016). The NYT caldera resurgence is ostensibly associated with significant deformation and uplift of the inner caldera region, as indicated by the growth of strata on the flanks of the resurgent dome (Figure 11) as well as by the marine deposits nowadays exposed onshore with an elevation of $\sim 30 \mathrm{~m}$ a.s.l., onland Pozzuoli at La Starza (Cinque et al. 1985, Rosi \& SBRANA 1987, Di ViTo et al. 1999, ORSI et al. 1999). The apical part of the resurgent dome includes a small collapsed area, or apical graben (e.g. Komuro 1987, LIPMAN 1997, Cole et al. 2005) characterised by a swarm of high-angle normal faults associated with minor vertical displacement (5-12 m; Figure 8). Multibeam bathymetry coupled with seismic data evidences that the median sector of the Pozzuoli Bay is characterised by a morphostructural depression surrounding the resurgent dome, partly represented by the Epitaffio Valley in the western sector of the Pozzuoli Bay and the Bagnoli Valley to the east (SommA et al. 2016; Figure 3), that correspond to actual segments of the caldera collar (e.g. LIPMAN 1997, Cole et al. 2005).

A striking feature imaged by profiles Seistec 111401 (Figure 12) and Seistec 111223 towards the inner continental shelf of the Bay of Pozzuoli (Figure 13) is represented by a prominent Infralittoral Prograding Wedge (IPW) (sensu HERNÁNDEZ-Molina et al. 2000), i.e. a sedimentary wedge consisting of prograding clinoforms that develop in the shoreface area below the storm wave base (see also PATRUNO \& HeLland-HANSEN 2018).

Seismic sections show that the main prograding wedger (IPW \#1) develops as a $\sim 5-10 \mathrm{~m}$ thick and $\sim 3 \mathrm{~km}$ long sedimentary prism elongated in WNW-ESE direction (see also SACCHI et al. 2014, MARINO 2018). Multibeam data coupled with seismic imaging indicate that the upper edge of the IPW clinoforms correspond to a pronounced inner shelf slope break, that is found at water depths varying from a minimum of $\sim-25 \mathrm{~m}$ offshore Baia to a maximum of $\sim-45$ $\mathrm{m}$ offshore Bagnoli-Nisida (Figure 3). 


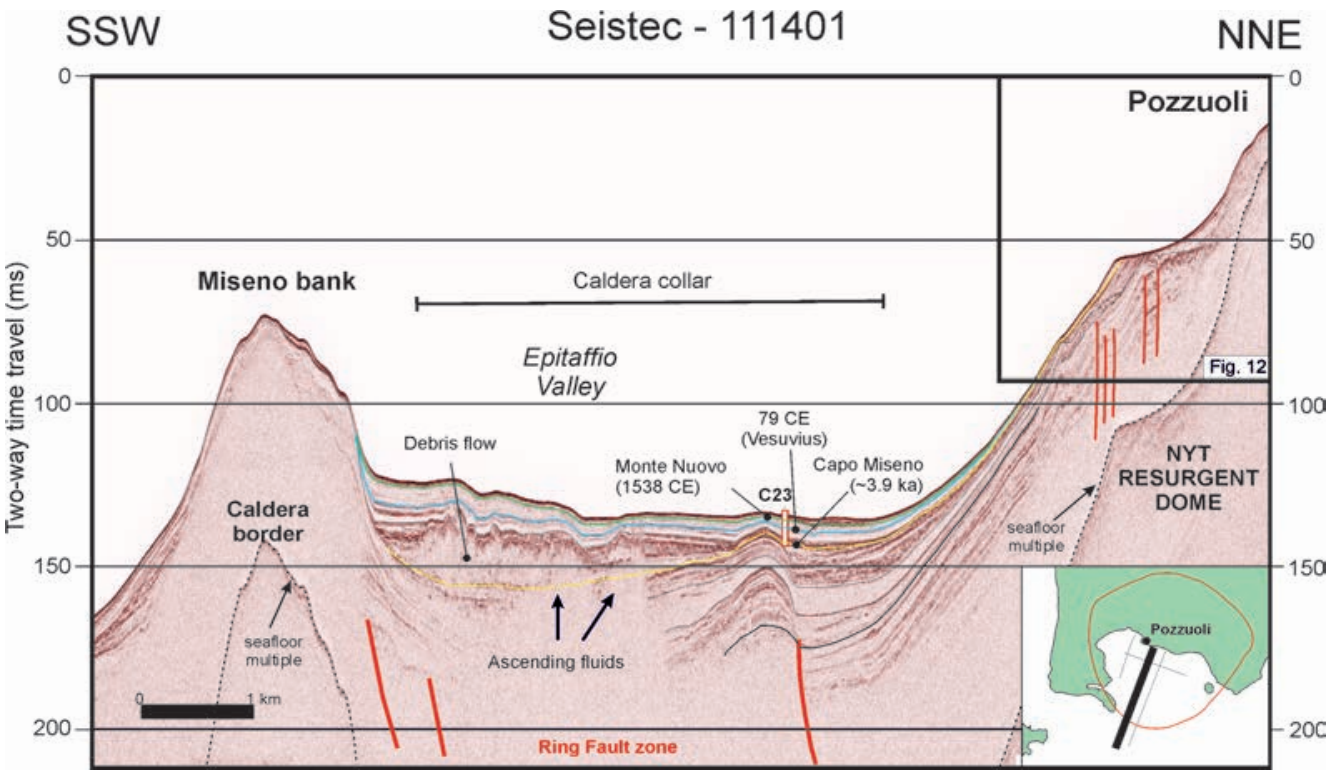

Figure 9. IKB-Seistec profile 111401 and its interpretation. The profile provides a section across the major structural components of the NYT collapse-resurgent caldera including (from NNE to SSW): 1) resurgent dome; 2) caldera collar and the underlying ring fault zone; 3) caldera border. Tephra layers associated with the eruptions of M. Nuovo (1538 CE) Vesuvius-Pompeii (79 CE) and C. Miseno ( 3.9 ka) are calibrated by gravity core C23 (see also Figure 7). Note debris flow units deposited along the Epitaffio Valley, and fluids ascending through the ring fault zone. Frame of Figure 12 is also indicated

9. ábra. 111401 IKB-Seistec szelvény értelmezése. A szelvény a NYT beszakadt kalderáján keresztül (ÉÉK-DDNy irányban) mutatja a föbb szerkezeti elemeket: 1) kiemelt kupola, 2) a kaldera pereme és az alatta lévó vetözóna, 3) a kaldera határa. A M. Nuovo (1538), Vezúv-Pompei (79) és C. Miseno ( 3.9 ka) kitöréseihez kapcsolódó tefra rétegek a gravitációs magminták adataival kalibráltak. (7. ábra). Az Epitaffio-völgyben lerakódott üledékek és a vetözónához kötődő fluidumfeláramlás szintén megfigyelhetö a szelvényen. A 12. ábra kivágatát is megjelöltük az ábrán

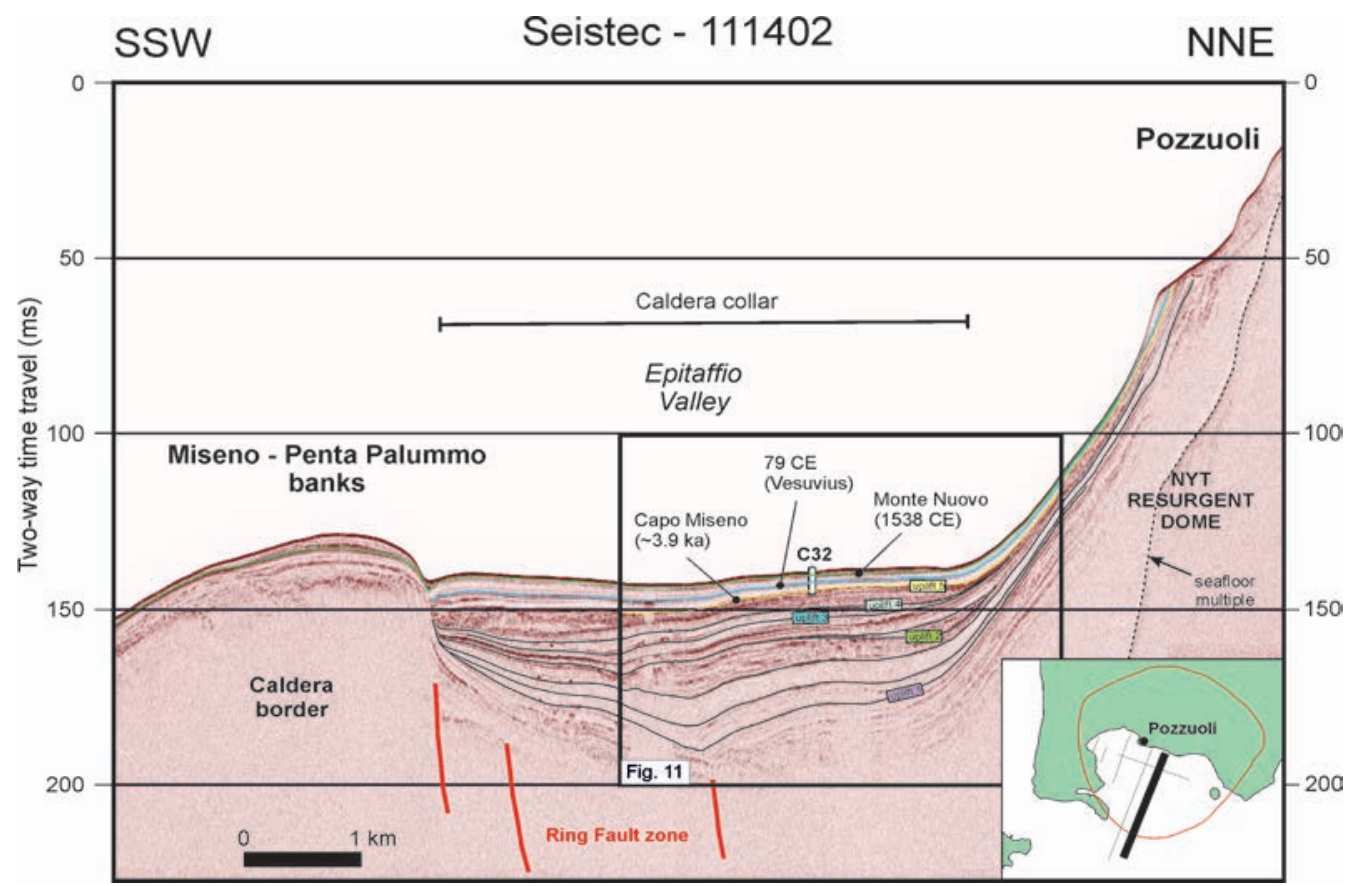

Figure 10. IKB-Seistec profile 111402 and its interpretation. The profile provides a section across the major structural components of the NYT collapse-resurgent caldera including (from NNE to SSW): 1) resurgent dome; 2) caldera collar and the underlying ring fault zone; 3 ) caldera border. Tephra layers associated with the eruptions of M. Nuovo (1538 CE) VesuviusPompeii (79 CE) and C. Miseno ( 3.9 ka) are calibrated by gravity core C32 (see also Figure 7). Unconformities denoted as Uplift $1-5$ are interpreted as the result of distinct phases of deformation and uplift of the resurgent structure during the last $\sim 12-5 \mathrm{ka}$. Frame of Figure 11 is also indicated.

10. ábra. 111402 IKB-Seistec szelvény értelmezése. A szelvény a NYT beszakadt kalderáján keresztül (ÉÉK-DDNy irányban) mutatja a föbb szerkezeti elemeket: 1) kiemelt kupola. 2) a kaldera pereme és az alatta lévö vetözóna, 3) a kaldera határa. A M. Nuovo (1538) Vezúv-Pompei (79) és C. Miseno ( 3.9 ka) kitöréseihez kapcsolódó tefrarétegek a gravitációs magminták adataival kalibráltak. (7. ábra). Az Uplift 1-5-el jelölt unkonformitások az elmúlt 5-12 ezer év során történt deformációk és kiemelkedések egyes fázisait jelölik. A 11. ábra kivágatát is jelöltük az ábrán 


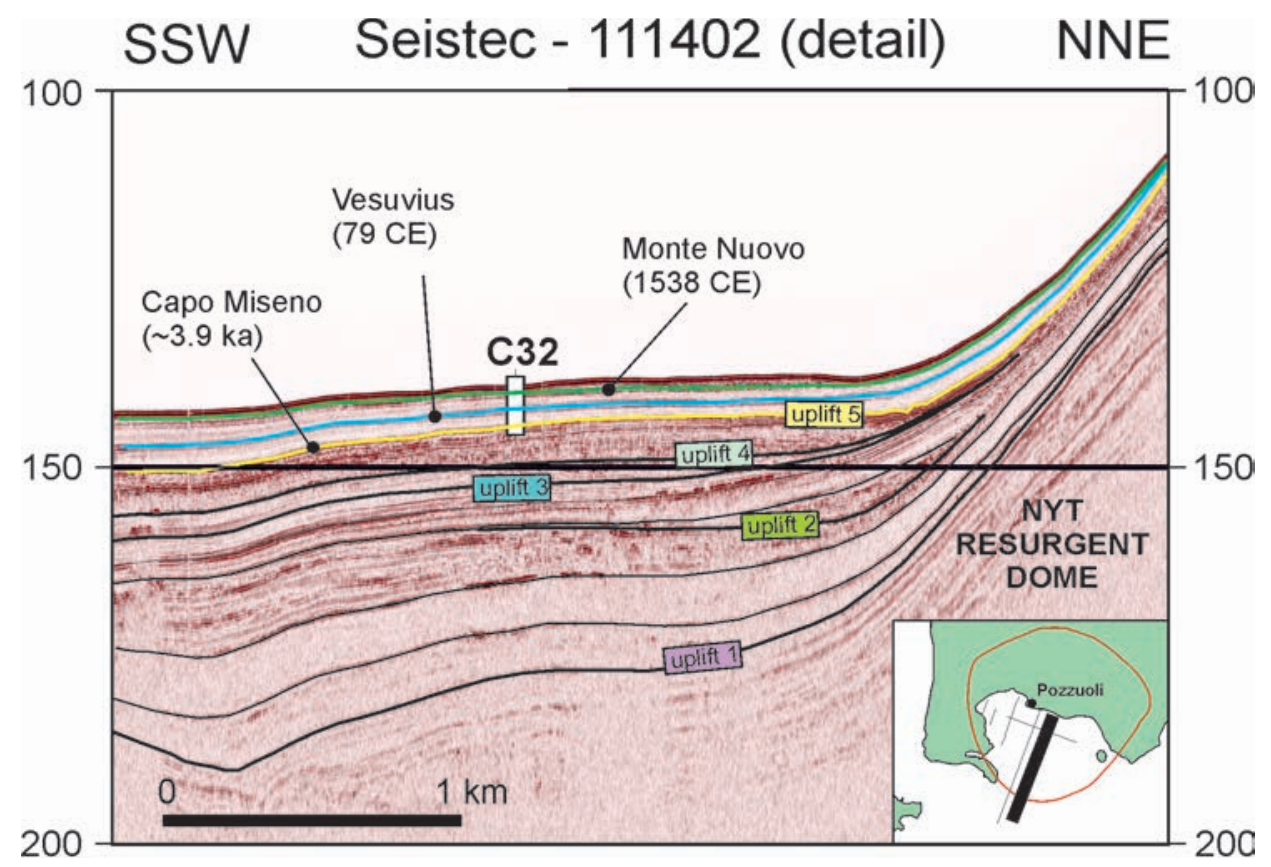

Figure 11. Detail of the IKB-Seistec profile 111402 and its interpretation showing the stratal architecture of seismic units bounded by unconformities denoted as Uplift 1-5 and calibration at C32 core site of major recent (shallower) tephra layers associated with the eruptions of M. Nuovo (1538 CE) Vesuvius-Pompeii (79 CE) and C. Miseno ( 3.9 ka). (See also Figures 7 and 10 for more information)

11. ábra. Az értelmezett 111402 IKB-Seistec szelvény részlete az Uplift 1-5-el jelölt unkonformitásokkal közrefogott rétegsorok szeizmikus képével. A sekély tefra rétegek a C32 magminta alapján lettek a M. Nuovo (1538), Vezúv-Pompei (79)és C. Miseno ( 3.9 ka) kitöréseihez kalibrálva. (A 7. és 10. ábrák további részleteket mutatnak.)

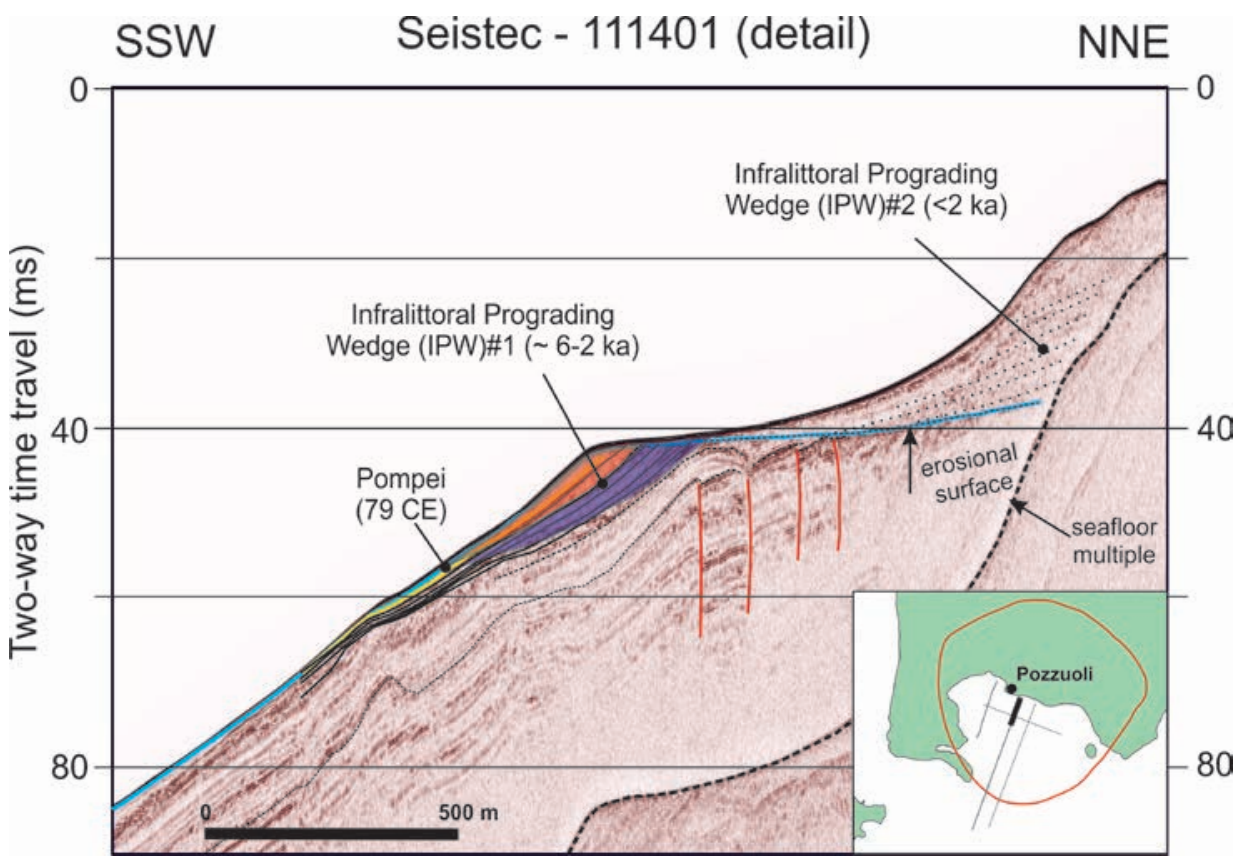

Figure 12. Detail of the IKB-Seistec profile 111401 and its interpretation. A prominent feature of the inner continental shelf of the Pozzuoli Bay is represented by an Infralittoral Prograding Wedge (sensu Hernández-Molina et al. 2000) (IPW \#1) that formed between $\sim 6-2$ ka, likely in response to a relatively long period of stable accommodation space Note that IPW \#1 is no longer in equilibrium with the present-day hydrodynamic processes and a younger Infralittoral Prograding Wedge (IPW \#2) developed in response to the post-Roman ( $<2 \mathrm{ka}$ ) subsidence and drowning of the Pozzuoli inner shelf area (SACCHI et al. 2014, MARINO 2018). See Figure 9 for location of this inset on seismic profile

12. ábra. Az értelmezett 111401 IKB-Seistec szelvény részlete. A Pozzuoli-öböl belsö kontinentális talapzatának jellegzetes eleme az IPW\#1 (belsö árapályövi progradációs sorozat), mely 2-6 ezer évvel ezelött keletkezett, feltehetöleg a hosszan fennálló akkomodációs tér hatására. Látható, hogy az IPW \#1 már nincs egyensúlyban. Ennek okai a jelenleg zajló hidrodinamikai folyamatok, a római kort követö ( 2 ezer évnél fiatalabb) süllyedés és a Pozzuoli belsö selföv elöntése során létrejött új IPW\#2 belsö árapályövi progradációs rétegsor. A 9. ábra mutatja a szelvényrészlet helyét a teljes szeizmikus szelvényen 


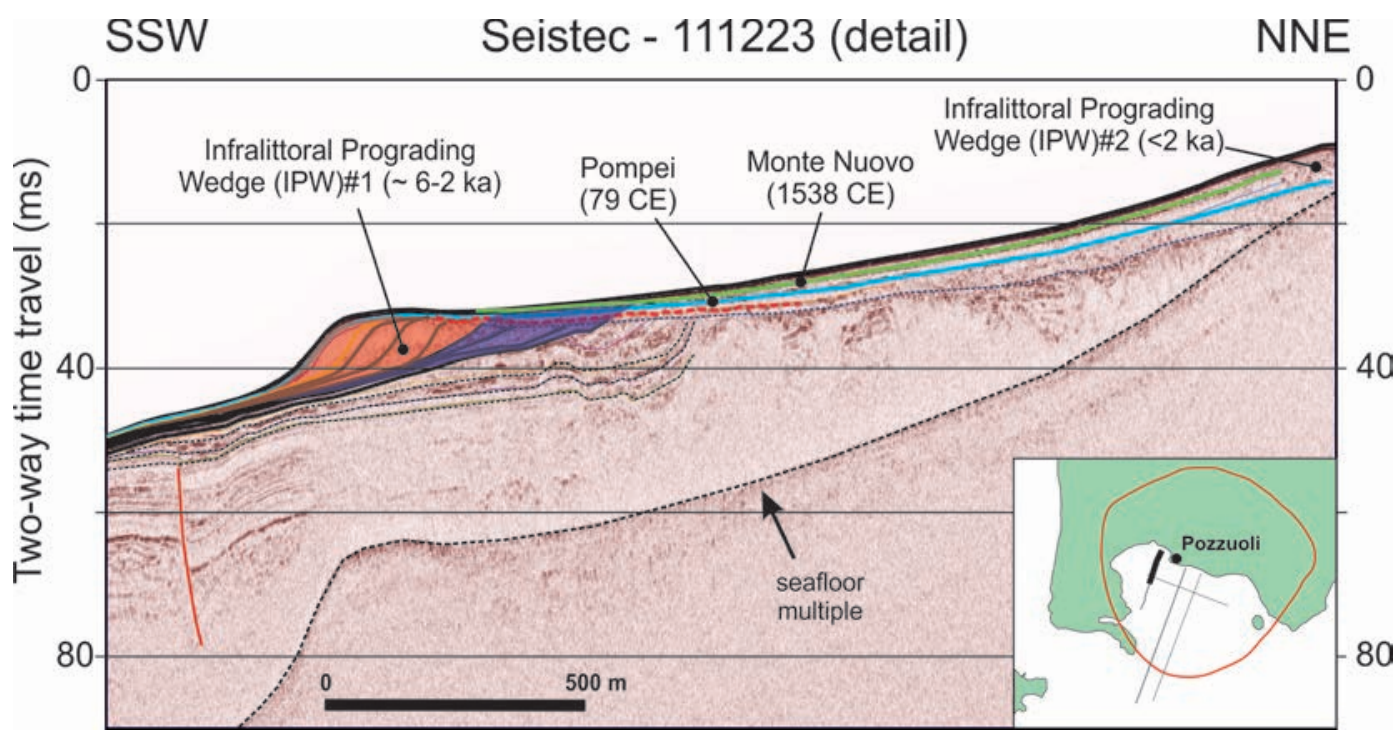

Figure 13. Detail of the IKB-Seistec profile 111223 and its interpretation showing the development of Infralittoral Prograding Wedge IPW \#1 ( 6-2 ka). Note the well-developed erosional slope and relatively thin (underdeveloped) IPW \#2, likely as a consequence of limited post-Roman ( $<2 \mathrm{ka}$ ) subsidence in the NW sector of the Pozzuoli Bay

13. ábra. Az értelmezett 111223 IKB-Seistec szelvény részlete az IPW \#1 (belsö árapályövi progradációs rétegsor) 2-6 ezer évvel ezelötti kifejlödésével. Megfigyelhetö a jól kifejlödött eróziós lejtö és a relativ vékony (fejletlen)IPW\#2, mely valószínüleg a római kort követö (2 ezer évnél fiatalabb) korlátozott mértékü süllyedéssel magyarázható a Pozzuoli-öböl ÉNy-i részében

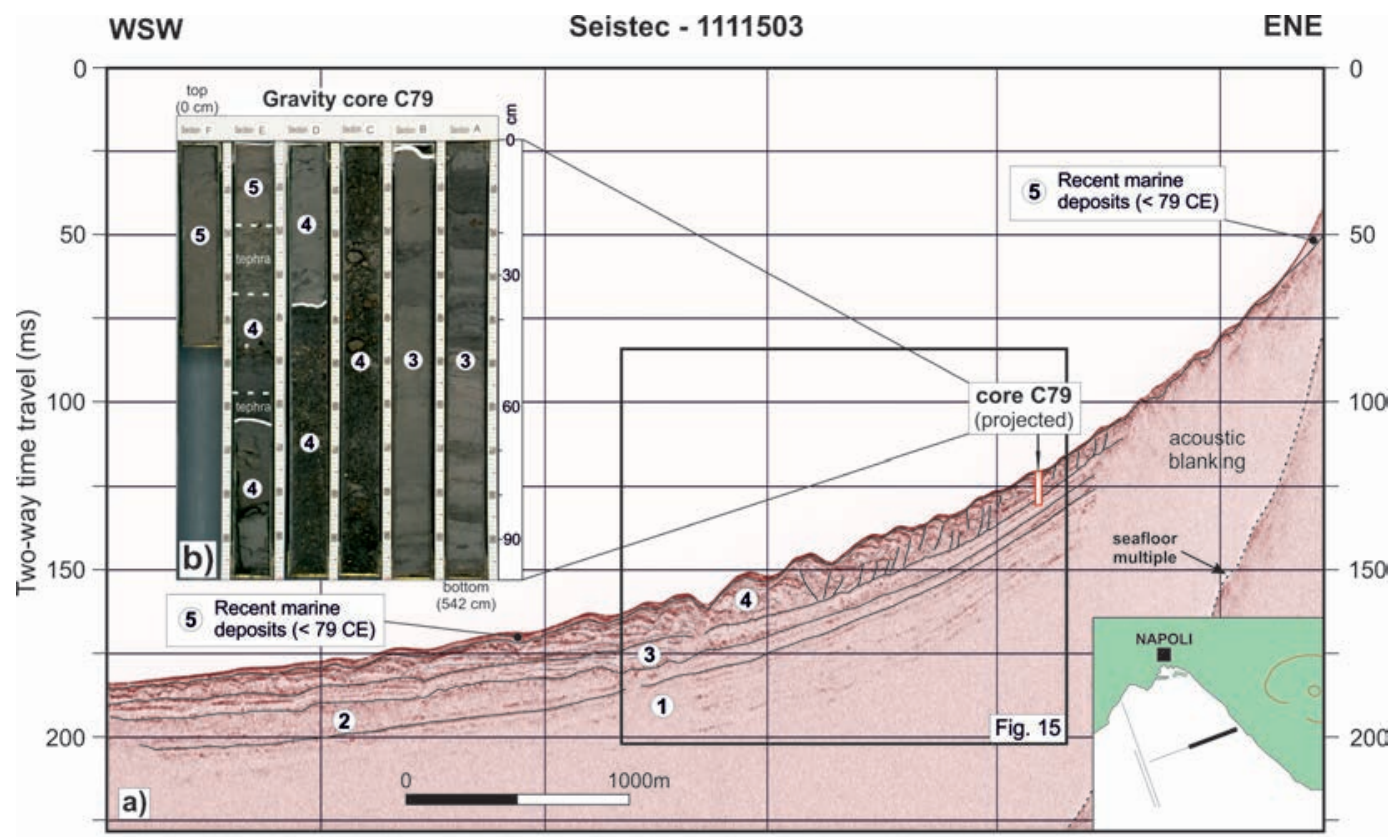

5 Post-Pompeil eruption marine deposits ( $<79 \mathrm{CE}$ ) 4 Reworked pyroclastic flow deposits (Vesuvius, $79 \mathrm{CE}$ ) 3 Marine siliciclastic deposits ( $3.5 \mathrm{ka}-79 \mathrm{CE}$ )

2 DA2 Volcanic Debris Avalance ( $3.5 \mathrm{ka}$ ) (after Milia et al, 2003) 1 Pre-Avellino (Vesuvius) eruption marine deposits (> $3.5 \mathrm{ka}$ )

Figure 14. a) IKB-Seistec profile 1111503 across the Herculaneum Sand wave Field (HSF), offshore Somma-Vesuvius, and its interpretation; b) Photograph of C79 core splits with interpreted lithofacies: 3) clayey silt and interbedded tephra (>CE 79); 4) coarsegrained pumice, and ash (pyroclastic flow deposits, Vesuvius, CE 79); 5) bioturbated clayey silt ( $<$ CE 79). See also the map of Figure 5 showing the onshore and offshore spatial distribution of the pyroclastic flow deposits that entered the sea during the 79 CE eruption of Vesuvius and location of seismic profile and gravity core C79.

14. ábra. a) Az értelmezett 1111503 IKB-Seistec szelvény a Herculaneum homokdünéken (HSF) keresztül, a Vezúv tengeri elöterében. b) A C79 felnyitott magminta fényképe az értelmezett litofáciesekkel. 3) agyagos közetliszt és közbetelepült tefra réteg (i.sz. 79-nél idösebb), 4) durva-szemcséjü horzsakö és hamu (piroklaszt-ár üledékei, Vezúv 79. évi kitörése), 5) bioturbált agyagos közetliszt (i.sz. 79-nél fiatalabb). Vesd össze a Vezúv 79. évi kitörése során tengerbe ömlött piroklaszt-ár 5. ábra térképén bemutatott szárazföldi és tengeri elterjedésével, valamint a szeizmikus szelvény nyomvonalával és a C79 gravitációs magminta helyével 
Seistec profiles also indicate the occurrence of at least a younger prograding wedge (IPW \#2) located at shallower depth in the upper shoreface area (e.g. Seistec 111401; Figure 12), in a more landward position with respect IWP $\# 1$, suggesting a phase of backstepping of the coastal system, likely due to increased accommodation space between the development of the two prograding systems.

\section{Somma-Vesuvius offshore}

Seistec profiles acquired offshore Herculaneum (Figure 5) document five, main seismic stratigraphic units denoted, from bottom to top as $1-5$, where units 5 to 3 have been reached and sampled by gravity core C79 (see MILIA et al. 2008) (Table 1 and Figures 14-15). Unit 1 is made of
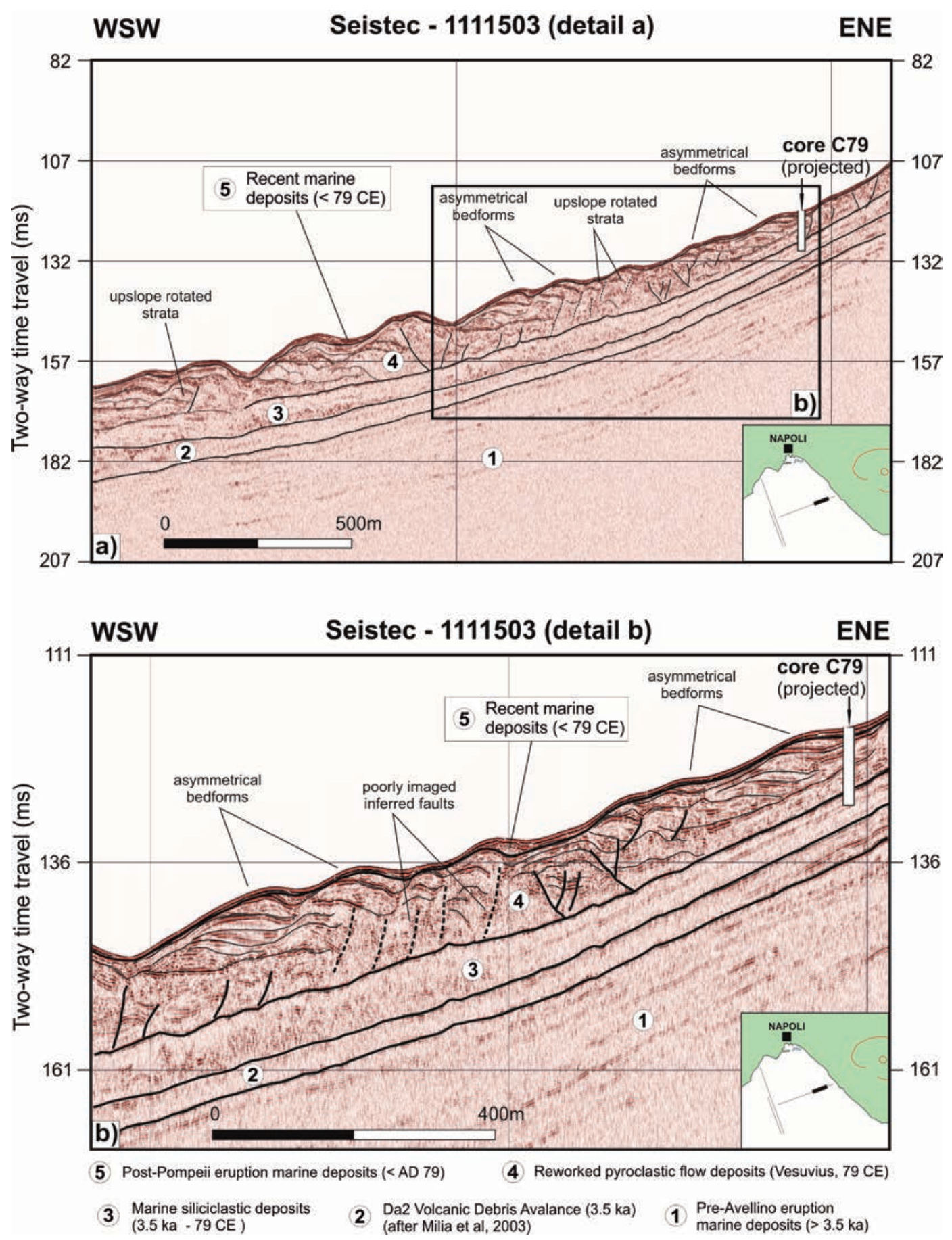

Figure 15. Details of IKB-Seistec profile 1111503 across the Herculaneum Sand wave Field (HSF) and their interpretation. Note wavy bedforms associated with the seaward modification and gravitational instability of the pyroclastic flow/surge deposits that entered the sea during the $79 \mathrm{CE}$ eruption of Vesuvius (see also Figure 14)

15. ábra. Az értelmezett 1111503 IKB-Seistec szelvény részlete a Herculaneum homokdünéken (HSF) keresztül. A szelvényen láthatók a Vezúv 79. évi kitörése során a tengerbe ömlö piroklaszt-ár gravitációsan összeomló homokhullámainak szerkezete (lásd még a 14. ábrát) 
parallel, relatively continuous high-amplitude reflectors and is overlain by unit 2, represented by a wedge-shaped geometry and internal chaotic to reflection-free seismic facies. The unit displays a thickness of $8-15 \mathrm{~m}$ and is locally imaged by parallel, discontinuous reflectors at its base. Up in the sequence follows unit 3 that displays a thickness of 5-10 m, with relatively continuous, highamplitude internal reflectors in the distal part of the slope and partly transparent seismic facies towards the coastal zone. The upper part of this unit (base of gravity core C79) is represented by laminated sandy silt interbedded with tephra layers that predate the Vesuvian eruption of $79 \mathrm{CE}$ (Milia et al. 2008) (Figure 14). The overlying unit 4 corresponds to pyroclastic flow deposits that have been reworked in marine environment after entering the seawater during the $79 \mathrm{CE}$ eruption of Vesuvius. In core C79 the deposits are mostly represented by coarse grained pumice, lapilli and ash at the base, and normally graded fine grained lapilli and ash with parallel lamination in the upper part of the succession (Figure 14). Unit 4 is mainly characterised by a wavy seismic facies that passes landward to wavy bedforms, with partially disrupted and chaotic reflections. The unit displays an average thickness of $12 \mathrm{~m}$ and covers an area of $\sim 30 \mathrm{~km}^{2}$ (Figures 5 and 14-15), yielding a volume of $\sim 80 \mathrm{~km}^{3}$. The uppermost part of the succession is represented by unit 5 that consists of wavyparallel reflectors blanketing the underlying unit 4 , with a thickness in the order of 1-4 m. The deposits of unit 5 correspond the uppermost interval sampled at C79 gravity core station and are represented by a homogeneous, partly bioturbated very fine sandy silt that postdates the $79 \mathrm{CE}$ eruption of the Vesuvius.

The planform morphology of the multilayer composed of units 4 and 5 defines an elongated, s-shaped, channelised

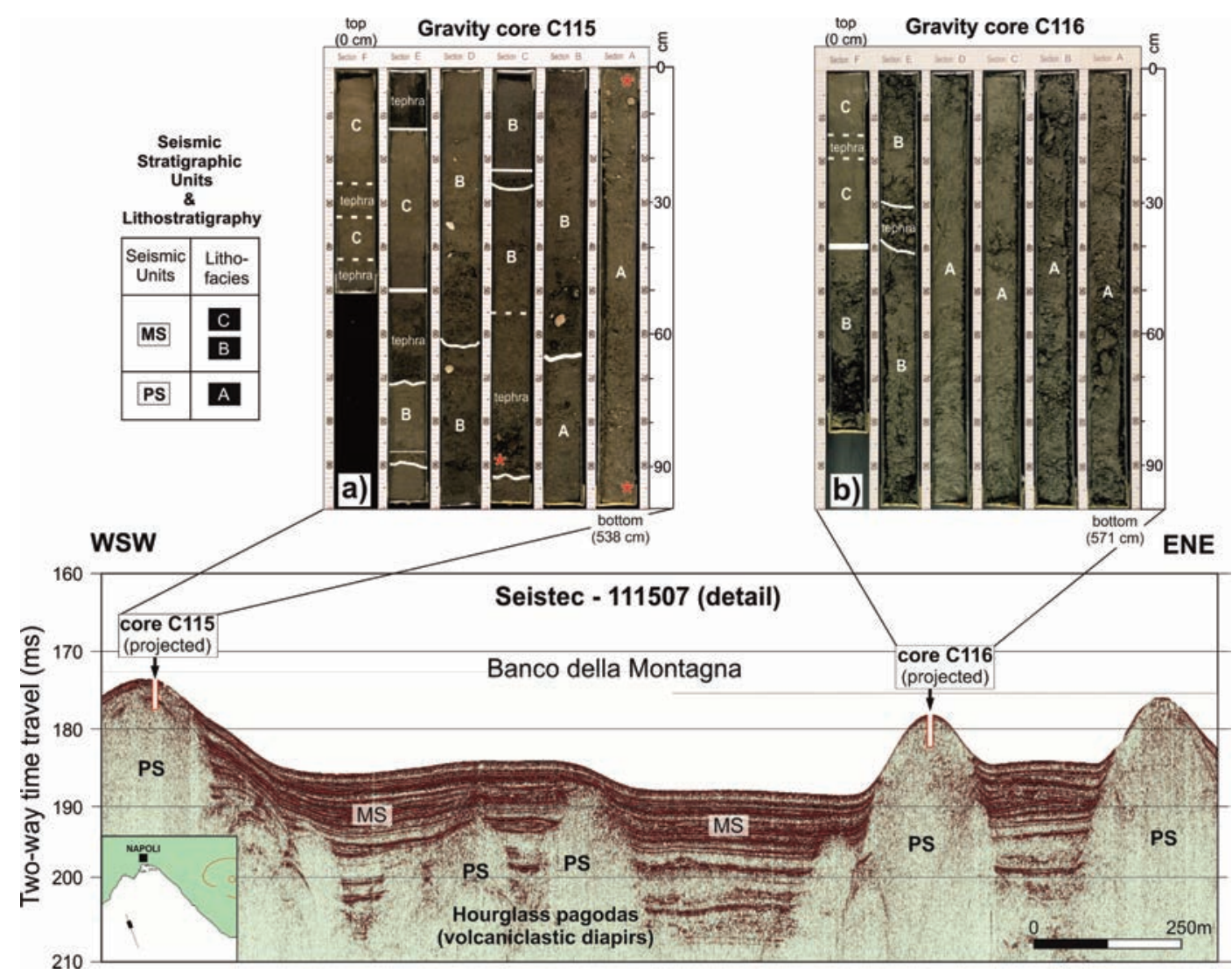

Figure 16. IKB-Seistec profile 1111507 across the volcaniclastic diapir field of Banco della Montagna and its interpretation. Geological calibration of seismic units was provided by gravity cores C115 and C116. Seismic stratigraphic units: MS) Post-LGM marine deposits; PS) coarse-grained, reworked volcaniclastics (mostly pumice). Lithofacies associations of C115 (frame a) and C116 (frame b) core splits: A) coarse-grained pumice and ash with chaotic texture including reworked products from NYT (ca $15 \mathrm{ka}$ ) and/or Pomici Principali ( 12 cal ka BP) eruptions; B) silty sand with mollusks and rhodoliths (13-10 ka BP); C) clayey silt with interbedded tephra $(<10 \mathrm{ka} B P)$. Red asterisks in photograph of core $\mathrm{C} 115$ mark stratigraphic position of samples processed for chemical analyses and ${ }^{40} \mathrm{Ar} /{ }^{39} \mathrm{Ar}$ determinations (INSINGA 2003)

16. ábra. Az értelmezett 1111507 IKB-Seistec szelvény a Banco della Montagna vulkáni diapírjén keresztül. A szeizmikus egységek geológiai korrelációja a C115 és C116 gravitációs magminták segítségével történt. MS) LGM utáni tengeri üledékek, PS) durva-szemcsés, áthalmozott vulkanoklaszt (föként horzsakö). A C115 (a) és C116 (b) felnyitott magminták fényképei az értelmezett litofáciesekkel. A) a NYT mintegy 15 ezer éves és/vagy a Pomici Prinicipali mintegy 12 ezer évvel ezelötti áthalmozott anyagát tartalmazó kaotikus szövetü, durvaszemcsés horzsakö és hamu, B) molluszka és rhodolit tartalmú agyagos homok (mintegy 10-13 ezer éves), C) agyagos közetliszt közbetelepült tefrarétegekkel (10 ezer évesnél fiatalabb). A C115 mag fényképén látható piros csillagok a kémiai vizsgálatokra és ${ }^{40} \mathrm{Ar}{ }^{39} \mathrm{Ar}$ meghatározásra vett minták helyeit jelölik (INSINGA 2003 nyomán) 
field of wavy bedforms, with a length of $\sim 13 \mathrm{~km}$ and width of $2-3 \mathrm{~km}$ that spreads away from the Herculaneum shoreline towards the central sector of the Bay of Naples (HSF; (Figures 5 and 14-15). Wavy bedforms display maximum amplitude of $\sim 10 \mathrm{~m}$ and wavelength in the order of 200-250 $\mathrm{m}$. In cross section, unit 4 displays basal, parallel reflectors onlapping an erosional truncation (Figures 14-15). The internal structure is characterised by asymmetric, mostly upslope migrating, sediment waves from deep to shallow water (Figure 15).

Seismic interpretation documents for unit 4 the occurrence of three segments, with different internal stratigraphic architecture. In nearshore settings (10-50 m water depth) where the unit is thicker (ca $20 \mathrm{~m}$ ) and the slope is steeper $\left(\sim 30^{\circ}\right)$ sediment waves tend to display a chaotic/ disrupted seismic facies, locally with backward (upslope) rotated strata (Figure 15a,b).

In median areas, between 70 and $120 \mathrm{~m}$ water depth, with slope in the order of $15^{\circ}$, sediment waves clearly display their asymmetric geometry and evidence of upslope accretion of strata ("antidunes", Figures 14-15). Internal unconformities bounding individual stratigraphic units involved in the building and growth of sediments waves can be recognised. The distal part of unit 4 develops at water depth of 120-140 m, with an average slope attaining $\sim 8^{\circ}$ and is characterised by a gradual decrease in the amplitude of sediment waves that become progressively smoother and thinner, as water depths increases. The asymmetry of wavy reflectors is locally evidenced by upslope dipping lee side of sediment waves particularly between $140 \mathrm{~m}$ and $120 \mathrm{~m}$ of water depth (Figure 15b).

\section{Banco della Montagna knoll}

Seistec profile 111507 (Figure 16) documents two main seismic-stratigraphic units in the area of the Banco della Montagna (BM). Both units have been cored in their upper part by gravity cores $\mathrm{C} 115$ and C116 (Table I and Figure 16a, b).

The upper seismic unit (MS) displays sub-parallel reflectors with high to medium amplitude and lateral continuity (Figure 16). Analysis of gravity cores indicates this unit consists, from bottom to top, of two main lithofacies: B) shallow water (shoreface) bioclastic sand and silty sand with mollusc shells and rohodolites deposited during the Last Glacial Maximum (LGM); A) burrowed sandy silt and clayey silt postdating the LGM.

The lower unit (PS) is represented by homogeneus coarse grained pumice and ash (lithofacies C in Figure 16a, $b$ ), and it features a chaotic to transparent seismic facies associated with a series of columnar or hourglass-shape diapirs ("pagodas"; EMERY 1974, PASSARO et al. 2016). These structures may locally be covered by the younger deposits or exposed at the surface where they form a complex set of seafloor mounds (Figures 2 and 5). Seismic interpretation also suggest that diapirs of unit PS intrude, deform, and drag the strata of the above MS unit.
Chemical analysis of selected sediment samples from C115 core (INSINGA 2003, D' ARGENIO et al. 2004), showed a compositional affinity with the Pomici Principali (ca 12 cal ka BP) and the NYT ( $5 \mathrm{ka}$ ) explosive eruptions of Campi Flegrei, also in agreement with preliminary ${ }^{40} \mathrm{Ar} /{ }^{39} \mathrm{Ar}$ determinations (Figure 16).

\section{Discussion}

The joint acquisition of ultra-high resolution seismics, gravity core data and swath bathymetry provide unprecedented imaging of the stratigraphic and structural expression of the recent volcanism offshore the Campania coastal zone, both in the Campi Flegrei and SommaVesuvius offshore and in the marine sector between them.

\section{Seismic imaging of the Campi Flegrei, NYT Caldera off the Bay of Pozzuoli}

Historical unrest and recent ground deformation (bradyseism) at Campi Flegrei Caldera have been long documented in the literature (e.g. ORSI et al. 1999, DE NAtAle et al. 2001, Battaglia et al. 2006, Acocella 2010). However, whereas only spotted effects of the bradyseism can be detected onshore, more easily recognizable are perhaps the offshore consequences of accommodation space changes due to seafloor deformation, as they can be extensively identified on seismic profiles by the stratal terminations at boundaries of seismic stratigraphic units (e.g. VAil 1987, Hunt \& TuCKer 1992, CATunEANu 2019).

Seistec profiles show that the NTY caldera has a broad ellipsoidal shape in plan view, elongated in WNW-ESE direction, with axes of $\sim 9 \mathrm{~km}$ and $\sim 8 \mathrm{~km}$. Seismic images allow for the detection and mapping of a distinct caldera collapse and associated fault zone (ring fault system), along with an inner caldera resurgent dome that results in an antiformal structure covering about $9 \mathrm{~km}^{2}$ with a diameter of $\sim 5 \mathrm{~km}$. The maximum documented uplift offshore is in the order of $120-150 \mathrm{~m}$.

The resurgent structure displays relatively limited, internal brittle deformation, with the notable exception of its central summit area where a set of normal faults forms an "apical graben" as the consequence of extension, in the area of maximum convex curvature of the antiformal structure, similarly to other resurgent caldera systems (e.g. Timber Mountain dome, CARR \& QUINLIVAN 1968) (see also LIPMAN 1997, Cole et al. 2005).

Towards the borders of the caldera collapse, the ring-fault structure represents a highly permeable zone allowing for the ascent of fluids (e.g. Figure 9) locally accompanied by the emplacement of sub-surficial magmatic intrusions (Figure 8; SACCHI et al. 2014; StEINMANN et al. 2016, 2018; NATALE 2018).

Seismic interpretation suggest a possible kinematic reconstruction of the NYT caldera during the last $15 \mathrm{ka}$ (SACCHI et al. 2014, StEINMANN et al. 2016), that can be summarised into four main stages (Figure 17): 

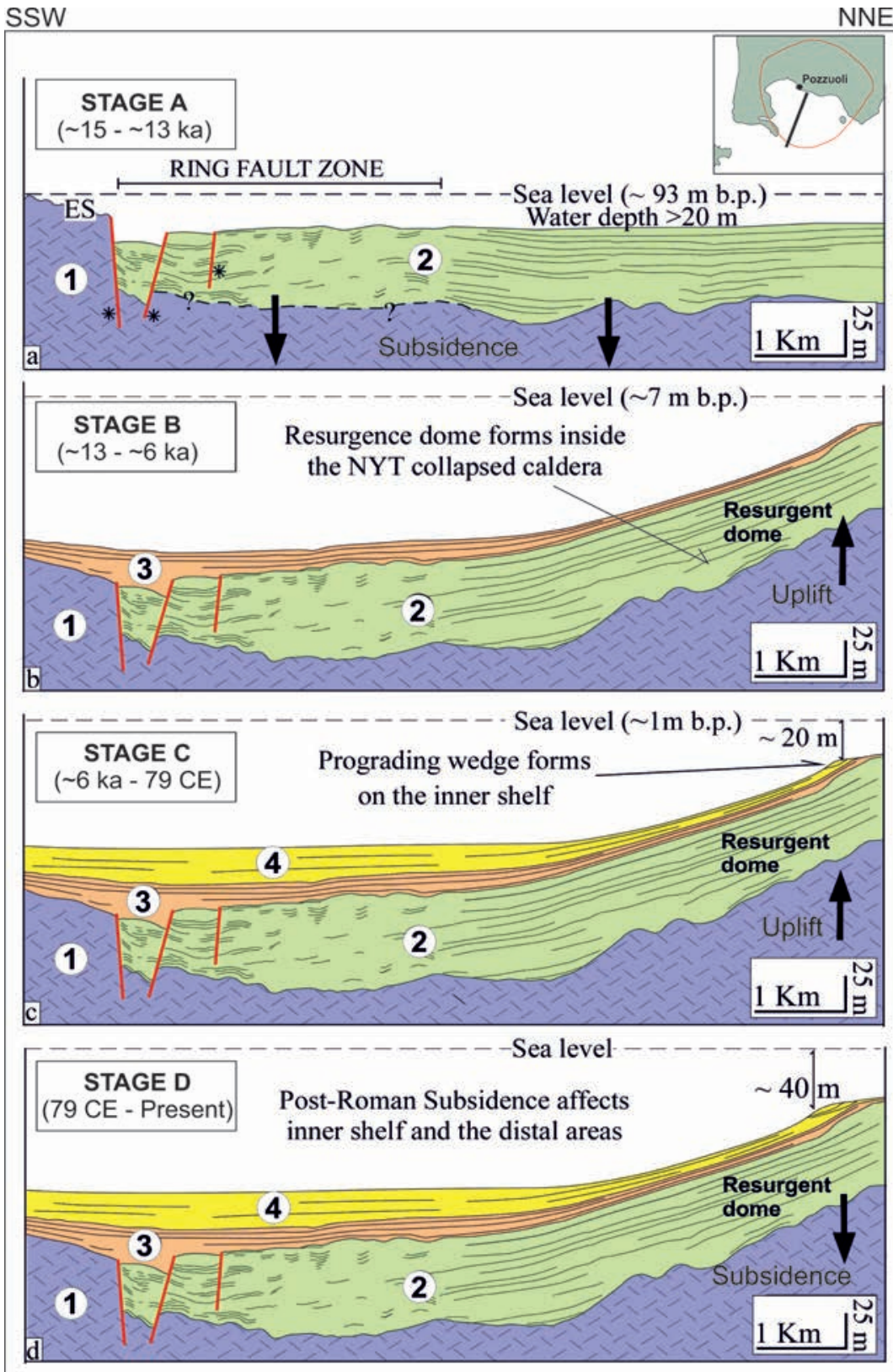

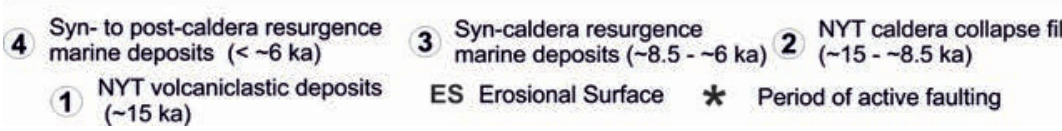

Figure 17. Stages of evolution of the NYT collapse-resurgent caldera during the last 15 kys (modified and redrawn after SACCHI et al. 2014). Vertical exaggeration is 1:8

17. ábra. A NYT kalderájának fejlödési fázisai. a) 13-15 ezer évvel ezelött, b) 6-13 ezer évvel ezelött, c) 6-2 ezer évvel ezelött, d) 2 ezer évvel ezelöttöl napjainkig. Az ábrán csillag jelöli az aktív vetöket. A nyilak a kiemelkedést/ süllyedést jelzik. Az ábra vertikális túlmagasítása 1,8-szeres (SACCHI et al. 2014 után módosítva)

- Stage A ( 15-13 ky) The first phase is characterised by onset of a rapid sediment filling of the inner caldera collapse, soon after the NYT eruption. The caldera fill reaches a thickness of $50-60 \mathrm{~m}$ and is represented by a succession of mixed volcaniclastic and siliciclastic deposits mostly fed by the surroundings of the caldera rim, with water depths rapidly changing from $80-90$ to $30-20 \mathrm{~m}$, prevailingly as a response to sediment input during a relatively short time interval dominated by sea level rise.
- Stage B ( 13-6 ky) During this stage, the concomitant deformation and uplift of the NYT resurgent dome $(\sim 12 \mathrm{~mm} /$ year on average) and the decrease in the rate of the eustatic sea level rise, result in a progressive decrease of the accommodation space within the inner shelf of the Pozzuoli Bay, causing subaerial exposure of marine strata between $\sim 8 \mathrm{ka}$ and $\sim 4 \mathrm{ka}$, along the coastal cliff (La Starza) (e.g. CinQue et al. 1985, AMORE et al. 1988).

- Stage C ( 6-2 ky) This period is characterised by a significant decrease in the rates of both the uplift of resurgent dome and sea level rise. The resulting phase of quasiequilibrium between the two processes and the consequent stability of the accommodation space, creates favorable conditions for the development of an Infralittoral Prograding Wedge (sensu HERNÁNDEZ-MolinA et al. 2000) (IWP\#1) off the Pozzuoli Bay, with slope break of prograding clinoforms likely located at an initial water depths of 20-22 m b.s.1. (FRACCASCIA et al. 2013, PEPE et al. 2104, SACCHI et al. 2014). The termination of this stage is constrained by the occurrence of the $79 \mathrm{CE}$ tephra layer of Vesuvius eruption, that has been cored in the Pozzuoli Bay, and can be traced into the uppermost part of the infralittoral prograding wedge (SACCHI et al. 2014)

- Stage D (Since $2.0 \mathrm{ka}$ ), a distinct phase of subsidence affects the inner sector of the NYT caldera as testified by dramatic drowning coastal settlements and infrastructures of Roman age (e.g. DVORAK \& BERRINO 1991, DVORAK \& MASTROLORENZO 1991). This time interval is characterised indeed by a period complex ground deformation including asymmetrical subsidence/ uplift (PASSARO et al. 2013). The generalised inner NYT caldera subsidence that was accompanied by an overall tilting of the entire resurgent structure towards ESE, that caused in turn the deactivation of the IWP\#1 formed during the previous stage (SACCHI et al. 2014, STEINMANN et al. 2016, MARINO 2018) and the overall landward backstepping of the shoreface depositional system with formation of a younger Infralittoral Prograding Wedge (IWP\#2) (Figure 910 and 12-13).

\section{Sediment wave field offshore Somma-Vesuvius}

The seafloor morphology offshore Somma-Vesuvius is largely influenced by the Late Holocene to recent volcanism. 
A major morphostructures is represented by the large channelised sand wave field (HSF), extending from the coasts of Herculaneum down to the SE flank of the Ammontatura Channel (Figure 5). Correlation between the stratigraphic succession documented onshore Herculaneum coast (Milia et al. 2008 and the offshore seismic units calibrated by gravity core data (Figures 14-15), allow for the recognition of the following seismic-stratigraphic units: 1) marine siliciclastic deposits older than $3.5 \mathrm{ka}$; 2) reworked pyroclastic flow deposits associated with the Avellino Plinian eruption ( 3.9 cal ka BP; "debris avalanche DA2" in MiLIA et al. 2003); 3) marine siliciclastic deposits that formed between $3.9 \mathrm{ka} \mathrm{BP}$ and the $79 \mathrm{CE}$; 4) pyroclastic flow/surge and fall deposits associated with the $79 \mathrm{CE}$ eruption of Vesuvius; 5) marine siliciclastic succession deposited after the $79 \mathrm{CE}$ eruption (Figures 14-15).

Seismic interpretation suggests that the HSF may be interpreted as the morphological expression of the submarine counterpart of pyroclastic flow and surge deposits of the Vesuvian Eruption of $79 \mathrm{CE}$ (unit 4) that entered the seawater after the destroying of Herculaneum (MiLIA et al. 2008, Pope et al. 2018). Particularly, the massive, homogeneous texture of the coarse grained pumice, lapilli and ash of unit 4 may result from the underwater modification of primary pyroclastic currents into turbulent flows (FREUNDT 2003, Le Friant et al. 2009, Trofimovs et al. 2012, JutZELER et al. 2017, Pope et al. 2018, SLOOTMAN et al. 2019 and references therein).

We also infer that the internal chaotic seismic facies and rupture of reflectors within sediment waves (Figures 14-15), mostly concentrated in the upper part of the HSF at water depths shallower than $100 \mathrm{~m}$, represent the effect of gravitational instability, locally manifested as slump folding/ faulting of strata within unit 4 along the upper slope. (e.g. POPE et al. 2018 and references therein).

\section{Volcaniclastic diapirs of the Banco della Montagna knoll}

Previous marine surveys acquired in the volcanic area of Napoli have documented a large, diffuse number of active fluid emissions and associated seafloor morphologies, like pockmarks, cones, and elongated features (PASSARO et al. 2014). Fluid vents are particularly concentrated on a subcircular seafloor region located between Campi Flegrei and Somma-Vesuvius at a depth of 150-100 m, 5 km SW off Naples harbor (PASSARO et al. 2016a).

The transparent facies of the columnar diapirs imaged on seismic profiles (unit PS) suggest a significant degree of mixing of unconsolidated pumiceous sediments and upraising gas, which was sampled at various locations from seafloor vents (PASSARO et al. 2016b). The gas composition is comparable with that of the Campi Flegrei and Somma-Vesuvius fumaroles and it is indicative of a mixing between a mantle source and shallower fluids associated with partial de-carbonation of crustal rocks (PASSARO et al. 2016).
The upward migration of gas within the sediments may also have the effect to scrub the materials included in unit MS, thus explaining the presence of chaotic structure of deposits sampled by the gravity cores. The integration of the results of previous studies (INSINGA 2003, D'ARGENIO et al. 2004, PASSARO et al. 2016) with seismic and gravity core data presented in this study suggest that the columnar and hourglass diapirs (pagodas) of the BM presumably formed by the dragging and uprise of unconsolidated pumice deposits (Pomici Principali and/or NYT erupted from the Campi Flegrei) from deeper stratigraphic levels to the surface, as a result of low-temperature degassing of over-pressured fluids. These layers are upward confined by a layer of silty deposits (facies C in Figure 16) that formed during the transgressive phase following the LGM $(<15$ $\mathrm{ka}$ ). The minimum overpressure was calculated to be at 2.4 MPa on average in the last 15 kyrs (VENTURA et al. 2016).

\section{Conclusion}

This study provides a series of ultra-high-resolution seismic images of selected volcanic structures, hydrothermal features and volcaniclastic depositional units that characterise the seafloor morphology and subsurface of the Bay of Naples off the Campi Flegrei Caldera and SommaVesuvius volcanic districts. Main conclusions may be summarised as follows:

1) The Pozzuoli Bay is characterised by the occurrence of an active resurgent dome associated with the late stage evolution of the Neapolitan Yellow Tuff (NYT) collapse caldera. The resurgent structure underwent a series of relatively rapid uplifts episodes alternating with unrest periods throughout the Late Pleistocene-Holocene, with a notable phase of subsidence approximately occurring between 2.5 and $1.5 \mathrm{ka}$. This style of deformation ostensibly controlled the long-term trend of ground deformation of the NYT intracaldera region throughout the Holocene. The resurgent dome is bounded at its periphery by a caldera ring-fault zone, locally characterised by the occurrence of ascending hydrothermal fluids and volcanic/subvolcanic intrusions.

2) Seismic imaging of the submarine slope of SommaVesuvius volcanic complex showed the occurrence of diffuse sand wave fields and seafloor instability along the outer shelf, involving the massive pyroclastic flow deposits that formed during the $79 \mathrm{CE}$ eruption of Vesuvius and entered the seawater after destroying the Roman city of Herculaneum.

3) A hummocky region at the seafloor (Montagna Bank) has been documented between the Somma-Vesuvius offshore and the Pozzuoli Bay, $\sim 5 \mathrm{~km}$ off the Posillipo hill. The Banco della Montagna was shaped by the dragging and rising up of unconsolidated pumiceous deposits (possibly including reworked material from NYT and Pomici Principali eruptions) from deeper stratigraphic horizons as a consequence of the overpressure associated with the emergence of active fluid vents in the area. 


\section{Acknowledgements}

This research is dedicated to the memory of our friend Ferenc (Feri) HoRvátH, who strongly believed in the use of high-resolution single channel reflection seismics as "the tool" for imaging the beauty of the geological architecture of shallow sedimentary strata and structures in areas of the Earth covered by water. We understand he was just right. We will also try to pass on the commitment we learned from him to those we work with and hopefully we will be inspired in that by Feri's unique blend of dedication, competence and humour.

IKB-Seistec reflection seismic data were acquired in 2013 on board of the Research Catamaran "Idrosfera" during Oceanographic cruises Seistec_13, in cooperation with Geomega Ltd, Budapest and the Eötvös University of
Budapest. Swath bathymetry and gravity core data used in this study were acquired by the IAMC-CNR, Naples, on board of the R/V Urania and Minerva Uno during a series of oceanographic cruises between 2000 and 2014. Major and trace-element content was analysed by a X-Ray fluorescence spectrometer at DiSTAR, (Napoli University "Federico II").

Financial support to this research was provided by the Programma Operativo Nazionale (PON) - Ricerca e Competitivita' 2007-2013 funded by the Italian Ministry of University and Research - Project MONICA (PON01_01525).

The authors wish to express their sincere thanks to Károly NÉMETH and Orsolya SzTANó for their critical comments on the manuscript.

\section{References - Irodalom}

Abdelmalak, M. M., Planke, S., Faleide, J. I., Jerram, D. A., Zastrozhnov, D., Eide, S. \& Myklebust, R. 2016: The development of volcanic sequences at rifted margins: New insights from the structure and morphology of the Vøring Escarpment, mid-Norwegian Margin. - Journal of Geophysical Research: Solid Earth 121/7, 5212-5236. https://doi.org/10.1002/2015JB012788

ACOCELla, V. 2010: Evaluating fracture patterns within a resurgent caldera: Campi Flegrei, Italy. — Bulletin of Volcanology 72, $623-638$. https://doi.org/10.1007/s00445-010-0347-x

ACOCELla, V. \& FUNICIELLO, R. 2006: Transverse systems along the extensional Tyrrhenian margin of central Italy and their influence on volcanism. - Tectonics 25, TC2003. https://doi.org/10.1029/2005TC001845

AitKen, J. F. \& Howell, J. 1996: High resolution sequence stratigraphy: Innovations, applications and future prospects. — Geological Society, London, Special Publications 104, 374 p. https://doi.org/10.1144/GSL.SP.1996.104.01.01

AMADIO, G. 1992: La cartografia in forma raster (Cartrograhpy in raster format). — Bollettino di geodesia e scienze affini 3, $227-242$.

Amore, O., Brancaccio, L., Ciampo, G., Cinque, A., Russo F., Sgarrella, F., Taddei, E., Barra, D. \& Sgrosso, L. 1988: Ulteriori considerazioni sui depositi marini de <La Starza>, presso Pozzuoli. - Atti Convegno di ricerca Università di Napoli, Regione Campania, Bradisismo e fenomeni connessi, Rei. Sciencia IV Rendiconti, 200-216, Napoli, 25-26 Marzo 1988.

Angkasa, S. S., Jerram, D. A., Millett, J. M., Svensen, H. H., Planke, S., Taylor, R. A., Schofield, N. \& Howell, J. 2017: Mafic intrusions, hydrothermal venting, and the basalt-sediment transition: Linking onshore and offshore examples from the North Atlantic igneous province. - Interpretation-a Journal of Subsurface Characterization 5/3, SK83-SK101. https://doi.org/10.1190/INT-20160162.1

Barberi, F., Cassano, E., La Torre, P. \& Sbrana, A. 1991: Structural evolution of Campi Flegrei Caldera in light of volcanological and geophysical data. — Journal of Volcanology and Geothermal Research 48/1-2, 33-49. https://doi.org/10.1016/0377-0273(91)90031$\mathrm{T}$

Battaglia, M., Troise, C., Obrizzo, F., Pingue, F. \& De Natale, G. 2006: Evidence for fluid migration as the source of deformation at Campi Flegrei caldera (Italy). — Geophysical Research Letter 33, L01307. https://doi.org/10.1029/2005GL024904

Bellucci, F., Milia, A., Rolandi, G. \& Torrente, M. M. 2006: Structural control on the Upper Pleistocene ignimbrite eruptions in the Neapolitan area (Italy): volcano tectonic faults versus caldera faults. — In: DE VIVo, B. (ed.): Volcanism in the Campania Plain: Vesuvius, Campi Flegrei and Ignimbrites. Amsterdam, Elsevier, Developments in Volcanology 9, 163-180. https://doi.org/ 10.1016/S1871-644X(06)80022-7

Berrino, G., Corrado, G., LuOngo, G. \& Toro, B. 1984: Ground deformation and gravity change accompanying the 1982 Pozzuoli uplift. — Bulletin of Volcanology 47/2, 187-200. https://doi.org/10.1007/BF01961548

Bischoff, A.P., Nicol, A. \& BEgGS, M. 2017: Stratigraphy of architectural elements in a buried volcanic system and implications for hydrocarbon exploration. — Interpretation 5/3, SK141-SK159. https://doi.org/10.1190/INT-2016-0201.1

Bodnar, R.J., Cannatelli, C., De Vivo, B., Lima, A., Belkin, H. E. \& Milia, A. 2007: Quantitative model for magma degassing and ground deformation (bradyseism) at Campi Flegrei, Italy: Implications for future eruptions. — Geology 35/9, 791-794. https://doi.org/10.1130/G23653A.1

Brocchini, D. Principe, C., Castradori, D. A., Laurenzi, M. \& Gorla, L. 2001: Quaternary evolution of the southern sector of the Campanian Plain and early Somma-Vesuvius activity: Insights from the Trecase 1 well. — Mineralogy and Petrology 73, 67-91. https://doi.org/10.1007/s007100170011

Capuano, P., Russo, G., Civetta, L., Orsi, G., D’Antonio, M. \& Moretti, R. 2013: The active portion of the Campi Flegrei caldera structure imaged by 3-D inversion of gravity data. — Geochemistry Geophysics Geosystems 14/10, 4681-4697. https://doi.org/ 10.1002/ggge.20276 
CARLINO, S. 2012: The process of resurgence for Ischia Island (southern Italy) since 55 ka: the laccolith model and implications for eruption forecasting. — Bulletin of Volcanology 74/5, 947-961. https://doi.org/10.1007/s00445-012-0578-0

CARr, W. J. \& Quinlivan, W. D. 1968: Structure of the Timber Mountain resurgent dome, Nevada Test Site. - Geological Society of America Memoirs 110, 99-108. https://doi.org/10.1130/MEM110-p99

Cassignol, C. \& Gillot, P. Y. 1982: Range and effectiveness of unspiked potassium-argon dating: Experimental ground work and application — In: Oodin, G. S. (ed.): Numerical Dating in Stratigraphy. J. Wiley and Sons, New York, 160-179.

Catuneanu, O. 2019: Scale in sequence stratigraphy. — Marine and Petroleum Geology 106, 128-159. https://doi.org/10.1016/ j.marpetgeo.2019.04.026

Cinque, A., Rolandi, G. \& Zamparelli, V. 1985: L'estensione dei depositi marini olocenici nei Campi Flegrei in relazione alla vulcanotettonica. — Bollettino della Società Geologica Italiana 104, 327-348.

Cioni, R., Bertagnini, A., Santacroce, R. \& Andronico, D. 2008: Explosive activity and eruption scenarios at Somma-Vesuvius (Italy): Towards a new classification scheme. — Journal of Volcanology and Geothermal Research 178, 331-346. https://doi.org/ 10.1016/j.jvolgeores.2008.04.024

COLE, P. D. \& SCARPATI, C. 1993: A facies interpretation of the eruption and emplacement mechanisms of the upper part of the Neapolitan Yellow Tuff, Campi Flegrei, southern Italy. — Bulletin of Volcanology 55, 311-326. https://doi.org/10.1007/BF00301143

Cole, J. W., Milner, D. M. \& Spinks, K. D. 2005: Calderas and caldera structures: a review. — Earth-Science Review 69, 1-26. https://doi.org/10.1016/j.earscirev.2004.06.004

Conticelli, S., Laurenzi, M.A., Giordano, G., Mattei, M., Avanzinelli, R., Melluso, L., Tommasini, S., Boari, E., Cifelli, F. \& PERINI, G. 2010: Leucite-bearing (kamafugitic/leucititic) and -free (lamproitic) ultrapotassic rocks and associated shoshonites from Italy: Constraints on petrogenesis and geodynamics. — Journal of the Virtual Explorer 36, https://doi.org/10.3809/ jvirtex.2010.00251

CserkéSz-NAgY, Á., Thamó-Bozsó, E., Tóth, T. \& SzTANó, O. 2012: Reconstruction of a Pleistocene meandering river in East Hungary by VHR seismic images, and its climatic implications. — Geomorphology 153-154, 205-218. https://doi.org/10.1016/ j.geomorph.2012.02.025

D’Argenio, B., Angelino, A., Aiello, G., De Alteris, G., Milia, A., Sacchi, M., Tonielli, R., Budillon, F., Chiocci, F., Conforti, A., De Lauro, M., Di Martino, G., D’Isanto, C., Esposito, E., Ferraro, L., Innangi, S., Insinga, D., Iorio, M., Marsella, E., Molisso, F., Morra, V., Passaro, S., Pelosi, N., Porfido, S., Raspini, A., Ruggieri, S., Sarnacchiaro, G., Terranova, C., Vilardo, G. \& Violante, C. 2004: Digital elevation model of the Naples bay and adjacent areas, eastern Tyrrhenian Sea. — In: PASQUARÉ, G., VeNTURINI, C. \& GropPeLLI, G. (eds): Mapping geology in Italy. Rome APAT, Dipartimento Difesa del Suolo-Servizio Geologico d'Italia, 21-28.

D’Oriano, C., Poggianti, E., Bertagnini, A., Cioni, R., Landi, P., Polacci, M. \& Rosi, M. 2005:Changes in eruptive style during the A.D. 1538 Monte Nuovo eruption (Phlegrean Fields, Italy): The role of syn-eruptive crystallization. — Bulletin of Volcanology 67, 601-621. https://doi.org/10.1007/s00445-004-0397-z

DE AlteriIs, G., Passaro, S. \& Tonielli, R. 2003: New, high-resolution swath bathymetry of Gettysburg and Ormonde Seamounts (Gorringe Bank, eastern Atlantic) and first geological results. — Marine Geophysical Researches 24, 223-244. https://doi.org/ 10.1007/s11001-004-5884-2

De Astis, G., Pappalardo, L. \& Piochi, M. 2004: Procida volcanic history: New insights into the evolution of the Phlegraean Volcanic District (Campania region, Italy). - Bulletin of Volcanology 66/7, 622-641. https://doi.org/10.1007/s00445-004-0345-y

De Natale, G., Troise, C., Pingue, F., De Gori, P. \& Chiarabba, C. 2001: Structure and dynamics of the Somma-Vesuvius volcanic complex. - Mineralogy and Petrology 73, 5-22. https://doi.org/10.1007/s007100170007

De Natale, G., Troise, C., Pingue, F., Mastrolorenzo, G., Pappalardo, L., Battaglia, M. \& Boschi, E. 2006: The Campi Flegrei caldera: Unrest mechanisms and hazards. — Geological Society, London, Special Publication 269, 25-45. https://doi.org/10.1144/ GSL.SP.2006.269.01.03

De Natale, G., Troise, C., Mark, D., Mormone, A., Piochi, M., Di Vito, M., A., Isaia, R., Carlino, S., Barra, D. \& Somma, R. 2016: The Campi Flegrei Deep Drilling Project (CFDDP): New insight on caldera structure, evolution and hazard implications for the Naples area (Southern Italy). — Geochemistry, Geophysics, Geosystems 17, 4836-4847. https://doi.org/10.1002/2015GC006183

de Vita, S., Orsi, G., Civetta, L., Carandente, A., D’Antonio, M., Deino, A., Di Cesare, T., Di Vito, M.A., Fisher, R.V., Isaia, R., Marotta, E., Necco, A., Ort, M., Pappalardo, L., Piochi, M. \& Southon, J. 1999: The Agnano-Monte Spina eruption (4100 years BP) in the restless Campi Flegrei caldera (Italy). — Journal of Volcanology and Geothermal Research 91, 269-301. https://doi.org/ 10.1016/S0377-0273(99)00039-6

De Vivo, B., Rolandi, G., Gans, P. B., Calvert, A., Bohrson, W. A., Spera, F. J. \& Belkin, H. E. 2001: New constraints on the pyroclastic eruptive history of the Campanian volcanic Plain (Italy). — Mineralogy and Petrology 73/1-3, 47-65. https://doi.org/ $10.1007 / \mathrm{s} 007100170010$

Deino, A.L., OrSI, G., DE VitA, S. \& Piochi, M. 2004: The age of the Neapolitan Yellow Tuff caldera-forming eruption (Campi Flegrei caldera, Italy) assessed by ${ }^{40} \mathrm{Ar} /{ }^{39} \mathrm{Ar}$ dating method. - Journal of Volcanology and Geothermal Research 133/1-4, 157-170. https://doi.org/10.1016/S0377-0273(03)00396-2

Dello Iacono, D., Zollo, A., Vassallo, M., Vanorio, T. \& Judenherc, S. 2009: Seismic images and rock properties of the very shallow structure of Campi Flegrei caldera (southern Italy). — Bulletin of Volcanology 71, 275-284. https://doi.org/10.1007/s00445-008-0222-1

Di CapuA, A. \& Groppelli, G. 2018: The riddle of volcaniclastic sedimentation in ancient deep-water basins: A discussion. Sedimentary Geology 378, 52-60. https://doi.org/10.1016/j.sedgeo.2018.05.008

Di Renzo, V., Di Vito, M. A., Arienzo, I., Carandente, A., Civetta, L., D’ Antonio, M., Giordano, F., Orsi, G. \& Tonarini, S. 2007 : Magmatic history of Somma-Vesuvius on the basis of new geochemical and isotopic data from a deep borehole (Camaldoli della Torre). — Journal of Petrology 48, 753-784. https://doi.org/10.1093/petrology/egl081 
Di Renzo, V., Arienzo, I., Civetta, L., D’Antonio, M., Tonarini, S., Di Vito, M. A. \& Orsi, G. 2011: The magmatic feeding system of the Campi Flegrei caldera: Architecture and temporal evolution. — Chemical Geology 281, 227-241. https://doi.org/10.1016/ j.chemgeo.2010.12.010

Di Vito, M.A., Isaia, R., Orsi, G., Southon, J., De Vita, S., D’Antonio, M., Pappalardo, L. \& Piochi, M. 1999: Volcanism and deformation since 12,000 years at the Campi Flegrei Caldera (Italy). - Journal of Volcanology and Geothermal Research 91/2-4, 221-246. https://doi.org/10.1016/S0377-0273(99)00037-2

Doglioni, C. 1991: A proposal for the kinematic modelling of W-dipping subsections-possible applications to the TyrrhenianAppennines system. — Terra Nova 3, 423-434. https://doi.org/10.1111/j.1365-3121.1991.tb00172.x

DVORAK, J. J. \& BERRINO, G. 1991: Recent ground movement and seismic activity in Campi Flegrei, southern Italy: episodic growth of a resurgent dome. - Journal of Geophysical Research 96, 2309-2323. https://doi.org/10.1029/90JB02225

DvoraK, J. \& MAStrolorenzo, G. 1991: The mechanisms of recent vertical crustal movements in Campi Flegrei caldera, southern Italy. - Special Paper Geological Society of America 263, 1-54. https://doi.org/10.1130/SPE263

EMERY, K. O. 1974: Pagoda structures in marine sediments. - In: KAPLAN, I. R. (ed.): Natural gases in marine sediments. New York, Plenum, 309-317. https://doi.org/10.1007/978-1-4684-2757-8_18

Faccenna, C., Mattei, M., Funiciello, R. \& Jolivet, L. 1997: Styles of back-arc extension in the central Mediterranean. — Terra Nova 9, 126-130. https://doi.org/10.1046/j.1365-3121.1997.d01-12.x

Fedele, L., Insinga, D. D., Calvert, A. T., Morra, V., Perrotta, A. \& Scarpati, C. 2011: ${ }^{40} \mathrm{Ar} /{ }^{39} \mathrm{Ar}$ dating of tuff vents in the Campi Flegrei caldera (southern Italy): Toward a new chronostratigraphic reconstruction of the Holocene volcanic activity. - Bulletin of Volcanology 73/9, 1323-1336. https://doi.org/10.1007/s00445-011-0478-8

Fedele, L., Scarpati, C., Sparice, D., Perrotta, A. \& Laiena, F. 2016: A chemostratigraphic study of the Campanian Ignimbrite eruption (Campi Flegrei, Italy): insights on magma chamber withdrawal and deposit accumulation as revealed by compositionally zoned stratigraphic and facies framework. - Journal of Volcanology and Geothermal Research 324, 105-117. https://doi.org/ 10.1016/j.jvolgeores.2016.05.019

Ferranti, L., Oldow, J. S. \& SACChI, M. 1996: Pre-Quaternary orogen-parallel extension in the Southern Apennine belt, Italy. Tectonophysics 260/4, 325-347. https://doi.org/10.1016/0040-1951(95)00209-X

Florio, G., Fedi, M., Cella, F. \& Rapolla, A. 1999: The Campanian Plain and Phlegrean Fields: structural setting from potential field data. - Journal of Volcanology and Geothermal Research 91, 361-379. https://doi.org/10.1016/S0377-0273(99)00044-X

Fraccascia, S., ChiocCi, F. L., SCROCCA, D. \& FALESE, F. 2013: Very high-resolution seismic stratigraphy of Pleistocene eustatic minima markers as a tool to reconstruct the tectonic evolution of the northern Latium shelf (Tyrrhenian Sea, Italy). — Geology 41, 375-378. https://doi.org/10.1130/G33868.1

FREUNDT, A. 2003: Entrance of hot pyroclastic flows into the sea: Experimental observations. — Bulletin of Volcanology 65, $144-164$. https://doi.org/10.1007/s00445-002-0250-1

García, M., Lobo, F. J., Maldonado, A., Hernández-Molina, F. J., Bohoyo, F. \& Pérez, L. F. 2016: High-resolution seismic stratigraphy and morphology of the Scan Basin contourite fan, southern Scotia Sea, Antarctica, — Marine Geology 378, 361-373. https://doi.org/10.1016/j.margeo.2016.01.011

Hernández-Molina, F. J., Fernández-Salas, L.M., Lobo, F. J., Somoza, L., Díaz del Río, V. \& Alveirinho Dias, J. M. 2000: The infralittoral prograding wedge: a new largescale progradational sedimentary body in shallow marine environments. - Geomarine Letters 20, 109-117. https://doi.org/10.1007/s003670000040

Horváth, F., BerckHemer, H. \& StegenA, L. 1981: Models of Mediterranean Back-Arc Basin Formation. — Philosophical Transactions of the Royal Society of London, Series A - Mathematical Physical and Engineering Sciences 300/1454, 383-402. https://doi.org/ 10.1098/rsta.1981.0071

HunT, D. \& TUCKER, M. E. 1992: Stranded parasequences and the forced regressive wedge systems tract: deposition during base-level fall. - Sedimentary Geology 81, 1-9. https://doi.org/10.1016/0037-0738(92)90052-S

InsingA, D. 2003: Tephrostratigrapy of the upper Quaternary deposits of the Campania coastal zone (Tefrostratigrafia dei depositi tardoquaternari della fascia costiera campana). — PhD Thesis, Università degli Studi di Napoli Federico II, 202 p.

Insinga, D., Calvert, A. T., Lanphere, M. A., Morra, V., Perrotta, A., Sacchi, M., Scarpati, C., Saburomaru, J. \& Fedele, L. 2006: The Late-Holocene evolution of the Miseno area (southwestern Campi Flegrei) as inferred by stratigraphy, petrochemistry and 40Ar/39Ar geochronology. - In: De Vivo, B. (ed.): Volcanism in the Campania Plain: Vesuvius, Campi Flegrei and Ignimbrites. Developments in Volcanology 9, Elsevier, 97-124. https://doi.org/10.1016/S1871-644X(06)80020-3

Insinga, D., Molisso, F., Lubritto, C., SACChi, M., PAssariello, I. \& Morra, V. 2008: The proximal marine record of Somma-Vesuvius volcanic activity in the Naples and Salerno bays, Eastern Tyrrhenian Sea, during the last 3 kyrs. - Journal of Volcanology and Geothermal Research 177, 170-186. https://doi.org/10.1016/j.jvolgeores.2007.07.011

insinga, D. D., Tamburrino, S., Lirer, F., Vezzoli, L., Barra, M., De Lange, G. L., Tiepolo, M., Vallefuoco, M., Mazzola, S. \& Sprovieri, M. 2014: Tephrocronology of the astronomically-tuned KC01B deep-sea core, Ionian Sea insights into the explosive activity of the Central Mediterranean during the last 200 ka. — Quaternary Science Reviews 85, 63-84. https://doi.org/10.1016/ j.quascirev.2013.11.019

International Hydrographic Organization (IHO) 2008: IHO Standards for Hydrographic Surveys. — Special Publication 44, International Hydrographic Bureau: Monaco, 28

Isaia, R., D’Antonio, M., Dell'Erba, F., Di Vito, M. \& Orsi, G. 2004: The Astroni volcano: the only example of closely spaced eruptions in the same vent area during the recent history of the Campi Flegrei caldera (Italy). — Journal of Volcanology and Geothermal Research 133/1-4, 171-192. https://doi.org/10.1016/S0377-0273(03)00397-4

Jolivet, L., Faccenna, C. \& Piromallo, C. 2009: From mantle to crust: Stretching the Mediterranean, — Earth and Planetary Science Letter 285/1-2, 198-209. https://doi.org/10.1016/j.epsl.2009.06.017 
JudenHERC, S. \& Zollo, A. 2004: The Bay of Naples (Southern Italy): constraints on the volcanic structures inferred from a dense seismic survey. — Journal of Geophysical Research 109, B10312. https://doi.org/10.1029/2003JB002876

Jutzeler, M., Manga, M., White, J. D. L., Talling, P. J., Proussevitch, A. A., Watt, S. F. L., Cassidy, M., Taylor, R. N., Le Friant, A. \& IshizUKA, O. 2017: Submarine deposits from pumiceous pyroclastic density currents traveling over water: An outstanding example from offshore Montserrat (IODP 340). — Geological Society of America Bulletin 129/3-4, 392-414. https://doi.org/ 10.1130/B31448.1

Komuro, H. 1987: Experiments on cauldron formation: A polygonal cauldron and ring fractures. — Journal of Volcanology and Geothermal Research 31/1-2, 139-149. https://doi.org/10.1016/0377-0273(87)90011-4

Le Friant, A., Deplus, C., Boudon, G., Sparks, R. S. J., Trofimovs, J. \& Talling, P. 2009: Submarine deposition of volcaniclastic material from the 1995-2005 eruptions of Soufriere Hills volcano, Montserrat. _ Journal of the Geological Society 166, $171-182$. https://doi.org/10.1144/0016-76492008-047

Lericolais, G., Allenou, J. P., Berne, S. \& Morgan, P. 1990: A new system for acquisition and processing of very high-resolution seismic reflection data. — Geophysics 55/8, 1036-1046. https://doi.org/10.1190/1.1442916

Lima, A., De Vivo, B., Spera, F. J., Bodnar, R. J., Milia, A., Nunziata, C., Belkin, H. E. \& Cannatelli, C. 2009: Thermodynamic model for uplift and deflation episodes (bradyseism) associated with magmatic-hydrothermal activity at the Campi Flegrei (Italy). —Earth-Science Reviews 97, 44-58. https://doi.org/10.1016/j.earscirev.2009.10.001

LIPMAN, P. W. 1997: Subsidence of ash-flow calderas: Relation to caldera size and magma-chamber geometry. — Bulletin of Volcanology 59/3, 198-218. https://doi.org/10.1007/s004450050186

Lirer, L., Luongo, G. \& Scandone, R. 1987: On the volcanological evolution of Campi Flegrei. — Eos Transactions American Geophysical Union 68, 226-234. https://doi.org/10.1029/EO068i016p00226

Loeblich, A. R. \& TAPPAN, H. 1988: Foraminiferal Genera and their Classification. — Van Nostrand Reinhold, New York, 970 p.

Lucchi, F., Tranne, C. A., Calanchi, N., Pirazzoli, P. A., Romagnoli, C., Radtke, U., ReYss, J. L. \& Rossi, P. L. 2004: LateQuaternary ancient shorelines at Lipari (Aeolian Islands): stratigraphical constraints to reconstruct geological evolution and vertical movements. - Quaternary International 115, 105-115. https://doi.org/10.1016/S1040-6182(03)00100-9

Lucchi, F., Tranne, C. A., CAlanchi, N., Rossi, P. L. \& Keller, J. 2007: The stratigraphic role of marine deposits in the geological evolution of the Panarea volcano (Aeolian Islands, Italy). — Journal of the Geological Society 164, 983-996. https://doi.org/10.1144/ 0016-76492006-135

LUCCHI, F. 2009: Late-Quaternary terraced marine deposits as tools for wide-scale correlation of unconformity-bounded units in the volcanic Aeolian archipelago (southern Italy). — Sedimentary Geology 216/3-4, 158-178. https://doi.org/10.1016/j.sedgeo.2009.03.003

LUCCHI, F. 2019: On the use of unconformities in volcanic stratigraphy and mapping: Insights from the Aeolian Islands (southern Italy). — Journal of Volcanology and Geothermal Research https://doi.org/10.1016/j.jvolgeores.2019.01.014

Malinverno, A. \& RyAn, W. B. F. 1986: Extension on the Tyrrhenian Sea and shortening in the Apennines as results of arc migration driven by sinking of the lithosphere. - Tectonics 5, 227-245. https://doi.org/10.1029/TC005i002p00227

Manville, V., NÉmEth, K. \& KANO, K. 2009: Source to sink: a review of three decades of progress in the understanding of volcaniclastic processes, deposits, and hazards. — Sedimentary Geology 220, 136-161. https://doi.org/10.1016/j.sedgeo.2009.04.022

Marino, C. 2018: Volcano-tectonic movements in the Campi Flegrei resurgent caldera during the last 10 ky based on high-resolution seismic profile analysis in the Pozzuoli Bay. — Master's thesis, University of Naples Federico II, Naples, Italy, 86 p.

Martí, J., Groppelli, G. \& Brum DA SilveIRA, A. 2018: Volcanic stratigraphy: A review. - Journal of Volcanology and Geothermal Research 357, 68-91. https://doi.org/10.1016/j.jvolgeores.2018.04.006

Marturano, A., Isaia, R., Aiello, G. \& Barra, D. 2018: Complex Dome Growth at Campi Flegrei Caldera (Italy) in the Last 15 ka. — Journal of Geophysical Research: Solid Earth. https://doi.org/10.1029/2018JB015672

MCGEE, T. 1995: High-resolution marine reflection profiling for engineering and environmental purposes. Part A: Acquiring analogue seismic signals. - Journal of Applied Geophysics 33, 271-285. https://doi.org/10.1016/0926-9851(95)90046-2

MCGEE, T. 2000: High-resolution seismic profiling on water. - Annals of Geophysics 43/6, 1045-1073. https://doi.org/10.4401/ag-3688

Melluso, L., Morra, V., Brotzu, P., Razafiniparany, A., Ratrimo, V. \& Razafimahatratra, D. 1997: Geochemistry and Sr-isotopic composition of the late cretaceous flood basalt sequence of northern Madagascar: Petrogenetic and geodynamic implications. Journal of African Earth Sciences 24/3, 371-390. https://doi.org/10.1016/S0899-5362(97)00050-X

MiLiA, A. 1999: The geomorphology of Naples Bay continental shelf (Italy). _ Geografia Fisica e Dinamica Quaternaria 22/1, 73-78.

MiLiA, A. 2010: The stratigraphic signature of volcanism off Campi Flegrei (Bay of Naples, Italy). — Special Paper of the Geological Society of America 464, 155-170. https://doi.org/10.1130/2010.2464(08)

Milia, A. \& Torrente, M.M. 2000: Fold uplift and synkinematic stratal architectures in a region of active transtensional tectonics and volcanisms, Eastern Tyrrhenian Sea. — Bulletin of the Geological Society of America 112/10, 1531-1542. https://doi.org/10.1130/ 0016-7606(2000)112<1531:FUASSA>2.0.CO;2

Milia, A., Torrente, M. M. \& ZuppettA, A. 2003: Debris avalanches offshore of Somma-Vesuvius volcano, Italy: implications for volcanic hazard evaluation. — Journal of the Geological Society, London 160, 309-317. https://doi.org/10.1144/0016-764902-045

Milia, A., Molisso, F., Raspini, A., SACCHI, M. \& Torrente, M. M. 2008: Syneruptive features and sedimentary processes associated with pyroclastic currents entering the sea: the AD 79 eruption of Vesuvius, Bay of Naples, Italy. — Journal of the Geological Society, London 165, 839-848. https://doi.org/10.1144/0016-76492007-110

Molisso, F., Insinga, D., Marzaioli, F., SACCHI, M. \& LubritTo, C. 2010: Radiocarbon dating versus volcanic event stratigraphy: Age modelling of Quaternary marine sequences in the coastal region of the Eastern Tyrrhenian Sea. — Nuclear Instruments and Methods in Physics Research, Section B: Beam Interactions with Materials and Atoms 268/7-8, 1236-1240. https://doi.org/10.1016/ j.nimb.2009.10.142 
Mosher, D. C. \& Simpkin, P. G. 1999: Environmental marine geoscience 1. Status and trends of marine high-resolution seismic reflection profiling: Data acquisition. — Geoscience Canada 26/4, 174-188. https://journals.lib.unb.ca/index.php/GC/article/view/4024

NATALE, J. 2018: Structural frame and volcano-tectonic evolution of the Campi Flegrei resurgent dome in the Pozzuoli bay during the last 10 kys based on high-resolution seismic profiles analysis. - Master's thesis, University of Naples Federico II, Naples, Italy, 104 p.

Németh, K., Cronin, S. J., Stewart, R. B. \& Charley, D. 2009: Intra- and extra-caldera volcaniclastic facies and geomorphic characteristics of a frequently active mafic island-arc volcano, Ambrym Island, Vanuatu. — Sedimentary Geology 220/3-4, 256270. https://doi.org/10.1016/j.sedgeo.2009.04.019

NÉMETH, K. \& PALMER, J. 2018: Geological mapping of volcanic terrains: Discussion on concepts, facies models, scales, and resolutions from New Zealand perspective. — Journal of Volcanology and Geothermal Research. https://doi.org/10.1016/ j.jvolgeores.2018.11.028

Oldow, L.S., D’Argenio, B., Ferranti, L., PAppone, G., Marsella, E. \& SACChi, M. 1993: Large-scale longitudinal extension in the southern Apennines contractional belt, Italy. — Geology 21/12, 1123-1126. https://doi.org/10.1130/0091-7613(1993)021<1123:LSLEIT>2.3.CO;2

Orsi, G., D’Antonio, M., De Vita, S. \& Gallo, G. 1992: The Neapolitan Yellow Tuff, a large-magnitude trachytic phreatoplinian eruption: eruptive dynamics, magma withdrawal and caldera collapse. - Journal of Volcanology and Geothermal Research 53/1-4, 275-287. https://doi.org/10.1016/0377-0273(92)90086-S

OrSi, G., DE VitA, S. \& Di ViTo, M. 1996: The restless, resurgent Campi Flegrei nested caldera (Italy): constraints on its evolution and configuration. - Journal of Volcanology and Geothermal Research 74, 179-214. https://doi.org/10.1016/S0377-0273(96)00063-7

Orsi, G., Civetta, L., Del Gaudio, C., De Vita, S., Di Vito, M. A., Isaia, R., Petrazzuoli, S. M., Ricciardi, G. P. \& Ricco, C. 1999: Short-term ground deformations and seismicity in the resurgent Campi Flegrei caldera (Italy): An example of active blockresurgence in a densely populated area. - Journal of Volcanology and Geothermal Research 91/2-4, 415-451. https://doi.org/ 10.1016/S0377-0273(99)00050-5

Paoletti, V., D’Antonio, M. \& Rapolla, A. 2013: The structural setting of the Ischia Island (Phlegrean Volcanic District, Southern Italy): Inferences from geophysics and geochemistry. - Journal of Volcanology and Geothermal Research 249, $155-173$. https://doi.org/10.1016/j.jvolgeores.2012.10.002

Paoletti, V., Passaro, S., Fedi, M., Marino, C., Tamburrino, S. \& Ventura, G. 2016: Sub-circular conduits and dikes offshore the Somma-Vesuvius volcano revealed by magnetic and seismic data. — Geophysical Research Letters 43/18, 9544-9551. https://doi.org/10.1002/2016GL070271

Pappalardo, L., Civetta, L., D’ Antonio, M., Deino, A.L., Di Vito, M.A., Orsi, G., Caradente, A., De Vita, S., Isaia, R. \& Piochi, M. 1999: Chemical and Sr-isotopical evolution of the Phlegraean magmatic system before the Campanian Ignimbrite and the Neapolitan Yellow Tuff eruptions. — Journal of Volcanology and Geothermal Research 91, 141-166. https://doi.org/10.1016/S03770273(99)00033-5

Passaro, S., Barra, M., Saggiomo, R., Di Giacomo, S., Leotta, A., Uhlen, H. \& Mazzola, S. 2013: Multi-resolution morphobathymetric survey results at the Pozzuoli-Baia underwater archaeological site (Naples, Italy). — Journal of Archaeological Science 40/2, 1268-1278. https://doi.org/10.1016/j.jas.2012.09.035

Passaro, S., Genovese, S., Sacchi, M., Barra, M., Rumolo, P., Tamburrino S., Mazzola, S., Basilone, G., Placenti, F., Aroica, S. \& BONANNO, A. 2014: First hydroacoustic evidence of marine, active fluid vents in the Naples Bay continental shelf (Southern Italy). — Journal of Volcanology and Geothermal Research 285, 29-35. https://doi.org/10.1016/j.jvolgeores.2014.08.001

Passaro, S., Tamburrino, S., Vallefuoco, M., Gherardi, S., Sacchi, M. \& Ventura, G. 2016: High-resolution morpho-bathymetry of the Gulf of Naples, Eastern Tyrrhenian Sea. — Journal of Maps 12, 203-210. https://doi.org/10.1080/17445647.2016.1191385

Passaro, S., Tamburrino, S., Vallefuoco, M., Tassi, F., Vaselli, O., Giannini, L., Chiodini, G., Caliro, S., Sacchi, M., Rizzo, A. L. \& Ventura, G. 2016: Seafloor doming driven by degassing processes unveils sprouting volcanism in coastal areas. - Scientific Reports 6, 22448. https://doi.org/10.1038/srep22448

Passaro, S., SACChi, M., TAmburRino, S. \& Ventura, G. 2018: Fluid vents, flank instability, and seafloor processes along the submarine slopes of the somma-vesuvius volcano, Eastern Tyrrhenian margin. — Geosciences 8/2, p. 60. https://doi.org/10.3390/ geosciences 8020060

PATACCA, E., SARTORI, R. \& SCANDONE, P. 1990: Tyrrhenian basin and Apenninic arcs: kinematic relations since Late Tortonian times. Memorie Società Geologica Italiana 45, 425-451.

Patruno, S. \& Helland-Hansen, W. 2018: Clinoforms and clinoform systems: Review and dynamic classification scheme for shorelines, subaqueous deltas, shelf edges and continental margins. - Earth-Science Reviews 185, 202-233. https://doi.org/ 10.1016/j.earscirev.2018.05.016

PeCCeriLlo, A. 2005: Plio-Quaternary volcanism in Italy: Petrology, geochemistry, geodynamics. — Springer, Berlin, Heidelberg, 365 p. https://doi.org/10.1007/3-540-29092-3

PÉRÈs, J. M. \& PiCARD, J. 1964: Nouveau manual de Bionomie benthique de la Mer Méditerranée. — Recueil des Travaux de la Station Marine d'Endoume 47/31, 3-137.

Pepe, F., Ferranti, L., Sacchi, M., Bertotti, G., Collura, A. M. \& Sulli, A. 2014: Pattern and rate of post-20 ka vertical tectonic motion around the Capo Vaticano Promontory (W Calabria, Italy) based on offshore geomorphological indicators. — Quaternary International. http://dx.doi.org/10.1016/j.quaint.2013.11.012.

Perrotta, A., Scarpati, C., Luongo, G. \& Morra, V. 2010: Stratigraphy and volcanological evolution of Campi Flegrei and Procida island, Italy. - In: Stratigraphy and Geology of Volcanic Areas. Geological Society of America Special Papers 464, $185-189$. https://doi.org/10.1130/2010.2464(09)

Planke, S., Symonds, P. A., Alvestad, E. \& Skogseid, J. 2000: Seismic volcanostratigraphy of large-volume basaltic extrusive complexes on rifted margins. — Journal of Geophysical Research: Solid Earth 105(B8), 19335-19351. https://doi.org/10.1029/ 1999JB900005 
Planke, S., Millett, J. M., Maharjan, D., Jerram, D. A., Abdelmalak, M. M., Groth, A., Hoffmann, J., Berndt, C. \& Myklebust, R. 2017: Igneous seismic geomorphology of buried lava fields and coastal escarpments on the Vrring volcanic rifted margin. Interpretation a Journal of Subsurface Characterization 5/3, SK161-SK177. https://doi.org/10.1190/INT-2016-0164.1

Pope, E. L., Jutzeler, M., Cartigny, M. J. B., Shreeve, J., Talling, P. J., Wright, I. C. \& Wysoczanski, R .J. 2018: Origin of spectacular fields of submarine sediment waves around volcanic islands. - Earth and Planetary Science Letters 493 , $12-24$. https://doi.org/10.1016/j.eps1.2018.04.020

Principe, C., Tanguy, J. C., Arrighi, S., Paiotti, A., Goff, M. L. \& ZopPi, U. 2004: Chronology of Vesuvius' activity from A.D. 79 to 1631 based on archeomagnetism of lavas and historical sources. — Bulletin of Volcanology 66/8, 703-724. https://doi.org/10.1007/ s00445-004-0348-8

Reijenstein, H., Posamentier, H. \& Bhattacharya, J. 2011: Seismic geomorphogy and high-resolution seismic stratigraphy of innershelf fluvial, estuarine, deltaic, and marine sequences, Gulf of Thailand. — AAPG Bulletin 95, 1959-1990. https://doi.org/ $10.1306 / 03151110134$

Rolandi, G. 1998: The eruptive history of Somma-Vesuvius. — In: CoRTINI, M. \& DE VIVO, B. (ed.): Volcanism and Archaeology of the Mediterranean Area. Research Signpost, Trivandrum, India. 77-88.

Rolandi, G., Bellucci, F., Heizler, M. T., Belkin, H. E. \& DE Vivo, B. 2003: Tectonic controls on the genesis of ignimbrites from the Campanian Volcanic Zone, southern Italy. — Mineralogy and Petrology 79/1-2, 3-31. https://doi.org/10.1007/s00710-003-0014-4

Romagnoli, C., Casalbore, D., Ricchi, A., Lucchi, F., Quartau, R., Bosman, A., Tranne, C. A. \& Chiocci, F. L. 2018: Morphobathymetric and seismo-stratigraphic analysis of the insular shelf of Salina (Aeolian archipelago) to unveil its Late-Quaternary geological evolution. - Marine Geology 395, 133-151. https://doi.org/10.1016/j.margeo.2017.10.003

Rosi, M. \& SbranA, A. 1987: The Phlegrean Fields. - C.N.R. Quaderni de "La ricerca scientifica”, 175 p.

Rosi, M., PRINCIPE, C. \& VECCHI, R. 1993: The 1631 Vesuvius eruption. A reconstruction based on historical and stratigraphical data. — Journal of Volcanology and Geothermal Research 58/1-4, 151-182. https://doi.org/10.1016/0377-0273(93)90106-2

SACCHI, M., INFUSO, S. \& MARSELlA, E. 1994: Late Pliocene - Early Pleistocene compressional tectonics in offshore Campania (Eastern Tyrrhenian Sea). — Bollettino di Geofisica Teorica e Applicata 36, 141-144, 469-482.

Sacchi, M., Tonielli, R., Dövényi, P., Horváth, F., Magyari, O., Cserny, T., McGee, T. M. \& Mirabile, L. 1998: Seismic stratigraphy of the Late Miocene sequence beneath Lake Balaton, Pannonian Basin, Hungary. _ Acta Geologica Hungarica 41/1, 63-88.

SACCHI, M., HoRvÁTH, F. \& MAGYARI, O. 1999: Role of unconformity-bounded units in the stratigraphy of the continental record: a case study from the Late Miocene of the western Pannonian Basin, Hungary. — Geological Society, London, Special Publication 156, 357-390. https://doi.org/10.1144/GSL.SP.1999.156.01.17

Sacchi, M., Insinga, D., Milia, A., Molisso, F., Raspini, A.,Torrente, M. M. \& Conforti, A. 2005: Stratigraphic signature of the Vesuvius 79 AD event off the Sarno prodelta system, Naples Bay. — Marine Geology 222-223, 443-469. https://doi.org/ 10.1016/j.margeo.2005.06.014

Sacchi, M., Alessio, G., Aquino, I., Esposito, E., Molisso, F., Nappi, R., Porfido, S. \& Violante, C. 2009: Risultati preliminari della campagna oceanografica CAFE_07 - Leg 3 nei Golfi di Napoli e Pozzuoli, Mar Tirreno Orientale. — Quaderni di Geofisica 64, 326.

Sacchi, M., Pepe, F., Corradino, M., Insinga, D. D., Molisso, F. \& Lubritto, C. 2014: The Neapolitan Yellow Tuff caldera offshore the Campi Flegrei: Stratal architecture and kinematic reconstruction during the last 15ky. - Marine Geology 354, 15-33. https://doi.org/10.1016/j.margeo.2014.04.012

SANTACROCE, R. 1987: Somma-Vesuvius. - CNR Quaderni de “La Ricerca Scientifica” 114/8, p. 251.

Santacroce, R., Sulpizio, R., Zanchetta, G., Cioni, R., Marianelli, P., Sbrana, A., Donahue, D. J. \& Joron, J. L. 2008: Age and whole rocks-glass composition of proximal pyroclastics from the major explosive eruptions of Vesuvius: a review as a tool for distal tephrostratigraphy. - Journal of Volcanology and Geothermal Research 177, 1-8. https://doi.org/10.1016/j.jvolgeores.2008.06.009

Scandone, R., Bellucci, F., Lirer, L. \& Rolandi, G. 1991: The structure of the Campanian Plain and the activity of the Neapolitan volcanoes (Italy) — Journal of Volcanology and Geothermal Research 48, 1-31. https://doi.org/10.1016/0377-0273(91)90030-4

Scarpati, C., Cole, P. \& Perrotta, A. 1993: The Neapolitan Yellow Tuff — a large volume multiphase eruption from Campi Flegrei, Southern Italy. — Bulletin of Volcanology 55, 343-356. https://doi.org/10.1007/BF00301145

ScARPATI, C. \& PerrottA, A. 2012: Erosional characteristics and behavior of large pyroclastic density currents. - Geology 40/11, 10351038. https://doi.org/10.1130/G33380.1

Scarpati, C., Perrotta, A., Lepore, S. \& Calvert, A. 2013: Eruptive history of Neapolitan volcanoes: Constraints from 40Ar-39Ar dating. — Geological Magazine 150/3, 412-425. https://doi.org/10.1017/S0016756812000854

Schneider, J. L., Le Ruyet, A., Chanier, F., Buret, C., Ferriere, J., Proust, J. N. \& Rosseel, J. B. 2001: Primary or secondary distal volcaniclastic turbidites: how to make the distinction? An exam ple from the Miocene of New Zealand (Mahia Peninsula, North Island), — Sedimentary Geology 145/1-2, 1-22. https://doi.org/10.1016/S0037-0738(01)00108-7

Schneider, J. L., Pérez, F. J. P., Gimeno, D., Wassmer, P., Cabrera, M. \& Carracedo, J. C. 2004: Sedimentary signatures of the entrance of coarse-grained volcaniclastic flows into the sea: The example of the breccia units of the Las Palmas Detritic Formation (Mio-Pliocene, Gran Canaria, Eastern Atlantic, Spain). _ Journal of Volcanology and Geothermal Research 138, $295-323$. https://doi.org/10.1016/j.jvolgeores.2004.07.007

Schreilechner, M. G. \& Eichkitz, C. 2015: High Resolution Seismic Reflection in Geotechnical and Hydrogeological Applications. International Conference on Engineering Geophysics 2015, 4 p. https://doi.org/10.1190/iceg2015-003

Schwab, W. C., Denny, J. F., Foster, D. S., Lotto, L. L., Allison, M. A., Uchupi, E., Danforth, W. W., Swift, B. A., Thieler, E. R. \& Butman, B. 2003: High Resolution Quaternary Seismic Stratigraphy of the New York Bight Continental Shelf. — U.S. Geological Survey Open-File Report 2002-152. https://doi.org/10.3133/ofr2002152 
Segschneider, B., Landis, C. A., Manville, V., White, J. D. L. \& Wilson, C. J. N. 2002: Environmental response to a large, explosive rhyolite eruption: sedimentology of post-1.8 ka pumice-rich Taupo volcaniclastics in the Hawke's Bay region, New Zealand. Sedimentary Geology 150/3-4, 275-299. https://doi.org/10.1016/S0037-0738(01)00200-7

Sevink, J., van Bergen, M. J., van der Plicht, J., Feiken, H., Anastasia, C. \& Huizinga, A. 2011: Robust date for the Bronze Age Avellino eruption (Somma-Vesuvius): 3945 10 calBP (1995 \pm 10 cal BC). - Quaternary Science Reviews 30/9-10, 1035-1046. https://doi.org/10.1016/j.quascirev.2011.02.001

Sgarrella, F. \& Moncharmont Zei, M. 1993: Benthic foraminifera of the Gulf of Naples (Italy): Systematics and autoecology. Bollettino della Societŕ Paleontologica Italiana 32, 145-264.

SimpKIN, P. G. \& DAVIS, A. 1993: For seismic profiling in very shallow water, a novel receiver. — Sea Technology 34/9, $21-28$.

SMITH, R. L. \& BAILEY, R. A. 1968: Resurgent cauldrons. — Geological Society of America Memoirs 116, 613-662.

Smith, V., IsaiA, R. \& Pearce, N. J. G. 2011: Tephrostratigraphy and glass compositions of post-15 kyr Campi Flegrei eruptions: Implications for eruption history and chronostratigraphic markers. - Quaternary Science Reviews 30/25, 3638-3660. https://doi.org/10.1016/j.quascirev.2011.07.012

Slootman, A., Cartigny, M. J. B. \& Vellinga, A. J. 2019: Build-up-and-fill structure: The depositional signature of strongly aggradational chute-and-pool bedforms. - Marine and River Dune Dynamics - MARID VI. 213-218.

Somma, R., Iuliano, S., Matano, F., Molisso, F., Passaro, S., Sacchi, M., Troise, C. \& De Natale, G. 2016: High-resolution morphobathymetry of Pozzuoli Bay, southern Italy. — Journal of Maps 12/2, 222-230. https://doi.org/10.1080/17445647.2014.1001800

Steinmann, L., SPIESS, V. \& SACCHI, M. 2016: The Campi Flegrei caldera (Italy): formation and evolution in interplay with sea-level variations since the Campanian Ignimbrite eruption at $39 \mathrm{ka}$. - Journal of Volcanology and Geothermal Research 327, 361 -374. https://doi.org/10.1016/j.jvolgeores.2016.09.001

Steinmann, L., SpIESS, V. \& SACCHI, M. 2018: Post-collapse evolution of a coastal caldera system: Insights from a 3D multichannel seismic survey from the Campi Flegrei caldera (Italy). - Journal of Volcanology and Geothermal Research 349, 83-98. https://doi.org/10.1016/j.jvolgeores.2017.09.023

Trofimovs, J., Foster, C., Sparks, R. S. J., Loughlin, S., Le Friant, A., Deplus, C., Porritt, L., Christopher, T., Luckett, R., TAlLing, P. J., PALMER, M. R. \& LE BAS, T. 2012: Submarine pyroclastic deposits formed during the 20th May 2006 dome collapse of the Soufrière Hills Volcano, Montserrat. — Bulletin of Volcanology 74/2, 391-405. https://doi.org/10.1007/s00445-011-0533-5

VAIL, P. R. 1987: Seismic Stratigraphy Interpretation Using Sequence Stratigraphy: Part 1: Seismic Stratigraphy Interpretation Procedure. - AAPG Studies in Geology 27/1, 1-10.

Ventura, G., Passaro, S., Tamburrino, S., Vallefuoco, M. \& Sacchi, M. 2016: A model-estimation of gas overpressure in gas saturated layers in a volcanic setting: a case study from the Banco della Montagna (Naples Bay, Italy). — Proceedings of the 1st IMEKO TC-4 International Workshop on Metrology for Geotechnics (Benevento, Italy, March 17-18, 2016), 313-317.

Visnovitz, F., Horváth, F., FeKeTE, N. \& Spiess, V. 2015a: Strike-slip tectonics in the Pannonian basin based on seismic surveys at Lake Balaton. - International Journal of Earth Sciences 104/8, 2273-2285. https://doi.org/10.1007/s00531-015-1179-x

Visnovitz, F., Bodnár, T., Tóth, Zs., Spiess, V., Kudó, I., TimÁr, G. \& HorVÁth, F. 2015b: Seismic expressions of shallow gas in the lacustrine deposits of Lake Balaton, Hungary. — Near Surface Geophysics 13, 433-446. https://doi.org/10.3997/1873-0604.2015026

Wohletz, K., ORSI, G. \& DE VITA, S. 1995: Eruptive mechanism of the Neapolitan Yellow Tuff interpreted from stratigraphic, chemical and granulometric data. — Journal of Volcanology and Geothermal Research 67, 263-290. https://doi.org/10.1016/03770273(95)00002-C

ZeCChIn, M. \& CATUNEANU, O. 2013: High-resolution sequence stratigraphy of clastic shelves I: Units and bounding surfaces. — Marine and Petroleum Geology 39, 1-25. https://doi.org/10.1016/j.marpetgeo.2012.08.015

Zecchin, M., Baradello, L., Brancolini, G., Donda, F., Rizzetto, F. \& Tosi, L. 2008: Sequence stratigraphy based on high-resolution seismic profiles in the late Pleistocene and Holocene deposits of the Venice area. - Marine Geology 253/3-4, 185-198. https://doi.org/10.1016/j.margeo.2008.05.010

Manuscript recieved: 22/05/2019 